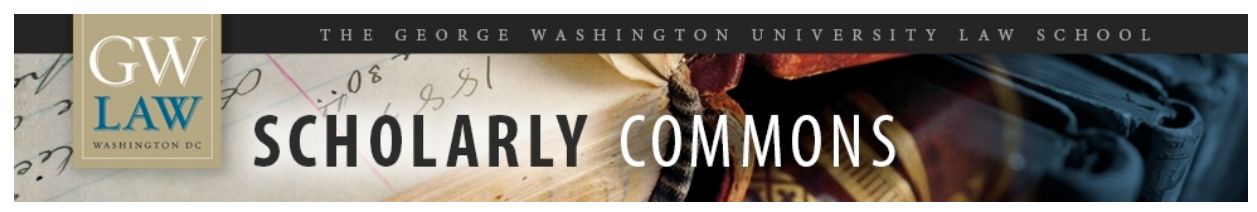

\title{
The FTC, IP, and SSOs: Government Hold-Up Replacing Private Coordination
}

\author{
F. Scott Kieff \\ George Washington University Law School, skieff@law.gwu.edu
}

Richard A. Epstein

Daniel F. Spulber

Follow this and additional works at: https://scholarship.law.gwu.edu/faculty_publications

Part of the Law Commons

\section{Recommended Citation}

F. Scott Kieff et. al., The FTC, IP, and SSOs: Government Hold-Up Replacing Private Coordination, J. Competition L. \& Econ. (2012).

This Article is brought to you for free and open access by the Faculty Scholarship at Scholarly Commons. It has been accepted for inclusion in GW Law Faculty Publications \& Other Works by an authorized administrator of Scholarly Commons. For more information, please contact spagel@law.gwu.edu. 
Keywords: patent, intellectual property, IP, antitrust, competition, standard setting organizations, SSO, hold-up, ex ante, RAND, innovation, property, contract, coordination, private ordering, new institutional economics

[Working Paper, draft of Sept. 14, 2011 - Forthcoming in the Journal of Competition Law \& Economics, Mar., 2012]

\title{
THE FTC, IP, AND SSOs: GOVERNMENT HOLD-UP REPLACING PRIVATE COORDINATION
}

\author{
Richard A. Epstein, ${ }^{*}$ F. Scott Kieff, ${ }^{\dagger} \&$ Daniel F. Spulber ${ }^{\ddagger}$
}

\begin{abstract}
In its recent report entitled "The Evolving IP Marketplace," the Federal Trade Commission (FTC) advances a farreaching regulatory approach (Proposal) whose likely effect would be to distort the operation of the intellectual property (IP) marketplace in ways that will hamper the innovation and commercialization of new technologies. The FTC Proposal relies on non-standard and misguided definitions of economic terms of art such as "ex ante" and "hold-up," while urging new inefficient rules for calculating damages for patent infringement. The FTC Proposal would so reduce the costs of infringement by downstream users that the rate of infringement would increase, as potential infringers find it in their interest to abandon the voluntary market in favor of a more attractive system of judicial pricing. As the number of nonmarket transactions increases, the courts will play an ever larger role in deciding the terms on which the patents of one party may be used by another party. The adverse effects of this new trend will do more than reduce the incentives for innovation; it will upset the current set of well-functioning private coordination activities in the IP marketplace that are needed to accomplish the commercialization of new technologies. Such a trend would seriously undermine capital formation, job growth, competition, and the consumer welfare the FTC seeks to promote.
\end{abstract}

We examine how these consequences play out in the context of standard-setting organizations (SSOs), whose activities are key to bringing standardized technologies to market. If the FTC's proposed definitions of "reasonable royalties" and "incremental damages" become the rules for calculating damages in patent infringement cases, the stage will be set to allow the FTC and private actors to attack, after the fact, all standard pricing methods through some combination of antitrust litigation or direct regulation on the ground that such time-honored royalty arrangements involve the use of monopoly power by patent licensors. The FTC's Proposal could well encourage potential licensees to adopt the very holdout strategies the FTC purports to address and that well-organized SSOs routinely counteract today. The FTC's proposal for regulating IP by limiting the freedom of SSOs to set their own terms would replace private coordination with government hold-up. The FTC should abandon its preliminary recommendations and support the current set of licensing tools that have fueled effective innovation and dissemination in the IP marketplace. FTC forbearance from its unwise Proposal will improve bargaining incentives, reduce administrative costs, and remove unnecessary elements of legal uncertainty in the IP system, thereby allowing effective marketplace transactions to advance consumer welfare.

JEL: A11, A12, B15, B25, D02, D04, D18, D23, D29, D40, D43, D61, D72, D78, D86, K11, K20, K21, K23, K29, K39, K41, K42, L12, L14, L24, L40, L43, L44, L51, L63, N70, O31, O33, O34, P14

\section{CONTENTS}

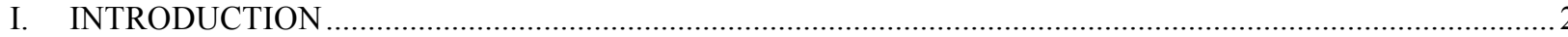

II. SSOs FACILITATE PRIVATE COORDINATION IN THE IP MARKETPLACE .........................................5

A. Standard Use of the Economic Term of Art "Ex Ante" Properly Focuses on the Time

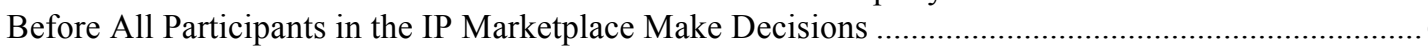

B. The Successful Track Record of SSOs' Powerful Incentives to Balance the Interest of Inventors and Manufacturers

\footnotetext{
" Epstein is the Laurence A. Tisch Professor of Law at New York University School of Law, the Peter and Kirsten Bedford Senior Fellow at Stanford University's Hoover Institution, and a senior lecturer at the University of Chicago Law School, where he is also the James Parker Hall Distinguished Service Professor of Law emeritus. Email: r-epstein@uchicago.edu.

$\lceil$ Kieff is a Professor at the George Washington University Law School and the Ray \& Louise Knowles Senior Fellow at Stanford University’s Hoover Institution. Email: skieff@law.gwu.edu.

* Spulber is the Elinor Hobbs Distinguished Professor of International Business and Professor of Management Strategy at the Northwestern University Kellogg School of Management. Email: jems@kellogg.northwestern.edu.

${ }^{1}$ Qualcomm retained the authors to analyze certain recommendations of the Federal Trade Commission (FTC) March 2011 report entitled "The Evolving IP Marketplace," and to offer their own views regarding those recommendations to Qualcomm and in a version of this paper that was submitted on August 5, 2011, in response to the FTC's Request for Comments and Announcement of Workshop on Standard-Setting Issues, Project No. P111204, dated May 13, 2011. The opinions expressed in this paper are those of the authors, who gratefully acknowledge intellectual, editorial, and research contributions provided by Roger G. Brooks and James E. Daily.
} 
C. The FTC Proposal Would Create SSOs that Would Not Work for Inventors or

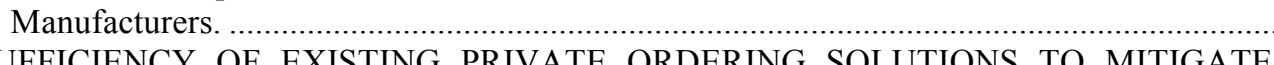

III. THE SUFFICIENCY OF EXISTING PRIVATE ORDERING SOLUTIONS TO MITIGATE
HOLD-UP RISK, INCLUDING LICENSES, REPUTATION THROUGH REPEAT PLAY, AND RAND COMMITMENTS

A. Participants in the IP Marketplace Typically Solve "Hold-Up" Problems Through Regular

Direct Interaction With Each Other

B. The Effectiveness of Bilateral Licensing

C. Restraining Opportunism with Reputation and Repeat Play ............................................................ 12

D. RAND Commitments and the Private Market ............................................................................. 12

E. Addressing the Risk of Reverse Hold-Up with SSO Rules ............................................................... 13

F. The Significant Informational Advantages of Private Parties over Governmental Actors .................... 14

G. The FTC Overstates Problems with Private Ordering Solutions ............................................... 14

IV. THE FTC's ILL-CONCEIVED AND INEFFICIENT PROPOSED CHANGES TO LONG-

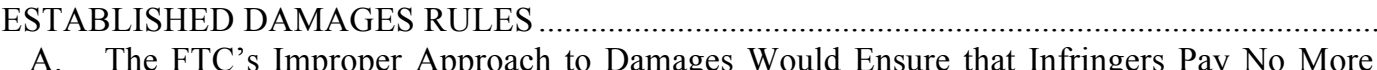

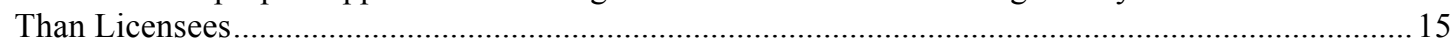

B. The Harmful Effects for Consumers of the FTC's Measure of Damages ...................................... 16

C. Using Damages to Encourage Private Ordering Rather Than Infringement ......................................16

D. The Effectiveness of Damages Approaches that Encourage Private Ordering ..................................17

E. Costs Imposed on Everyone in the IP Market by the FTC Approach ............................................ 18

F. Artificial Constraints Imposed on the Market by the FTC Approach ................................................ 19

G. The Ineffectiveness of Incremental Value in Calculating Damages...................................................221

H. The Fundamental Unsoundness of Taking Into Account the Infringement-Specific

Investments of the Infringer....

I. The Stark Inconsistency Between the FTC's Approach and the Key Role Historically

Played by Predictable Rules for Patent Enforcement in the Successful Commercialization

of Inventions as Well as Overall Competition and Social Welfare .....

V. CONCLUSION - A SOUND CASE FOR REGULATORY RESTRAINT …..............................................25

Appendix A - Excerpts from Qualcomm License Agreements .........................................................................2 27

\section{INTRODUCTION}

The Federal Trade Commission (FTC) report entitled The Evolving IP Marketplace: Aligning Patent Notice and Remedies with Competition (Report) sets forth a proposal for a far-reaching regulatory approach (Proposal) that, if adopted, would fundamentally distort and impede the intellectual property (IP) marketplace by disrupting three of its major institutions: (A) standard-setting organizations (SSOs), (B) markets, and (C) formal legal systems such as the law of patents, property and contract. These institutions are inter-dependent, such that the erosion of any one would significantly impede the others. Yet the FTC would disrupt each one, thereby injecting into the IP marketplace significant uncertainty and inefficiencies, thereby harming consumer welfare. The gist of the FTC Proposal is to replace the current set of well-functioning private coordination activities in the IP marketplace with a new set of rules that will lead to a major expansion in the role of both courts and government agencies in setting prices in routine transactions in the IP marketplace.

To be sure, the FTC Proposal does not seek to confer upon the agency any direct power to set the price of licenses. But if implemented, the FTC Proposal would achieve that end through a long process that runs as follows. At the first step, the FTC Rules all suggest that the currently observed prices in licensing arrangements are too high, and should instead be set in accordance with the FTC's own untested-but evidently unwiseapproach to "reasonable royalties" and "incremental damages," which are nowhere observed in the extensive practice within the industry. So long as such new approaches are made available to potential licensees as of right, they will have a strong incentive to abandon the voluntary market in order to obtain the benefit of such judicial pricing rules that are systematically more favorable to their interests. In the short run, therefore, it is likely that fewer downstream parties will enter into licensing agreements, in effect inviting patent holders to sue them in court, thereby creating major new risks of hold-up by downstream users. In addition, both the FTC and private parties may well seek to rely on the FTC Proposal as evidence that almost any license rates generated in the IP marketplace are too high. This skepticism about market rates may in turn make it too easy to invoke apprehensions about some "abuse of monopoly power" as justifications for either FTC or private actions under 
the antitrust law. The net impact from following the FTC Proposal would be to reduce the rate of return to innovators, who will either leave the market or accept lower prices for their wares. None of this is necessary. It has long been established that the owner of a patent does not have any necessary monopoly power by virtue of its exclusive right to sell its patented technology. ${ }^{2}$ A Patentee always faces competition from three sources: other patented technologies, new technologies that have yet to reach the market, and those technologies that have already fallen into the public domain. ${ }^{3}$

The impact of the FTC's Proposal would be particularly harsh on standard setting organizations, whose entire mode of operation is intended to avoid through advance planning the hold-up risks with respect to new technologies that the FTC wishes to avoid. Yet, by failing to appreciate the many procompetitive features of these organizations, the FTC Proposal could easily hamstring their use, thereby forcing ever greater reliance on systems of judicial or administrative pricing that are both costly to operate and uncertain in their effect. Strong damages for patent infringement are intended to eliminate the risk of infringement so that long-term cooperative efforts can strike the right balance between prices that are high enough to secure innovation and low enough to support its widespread dissemination. The failure to see how the various pieces of the full patent commercialization cycle fall into place makes it a virtual certainty that the FTC Proposals, if implemented, would yield a powerful government regulatory approach that will only have a blocking effect on the innovation and consumer welfare the FTC seeks to promote.

Since its inception, the U.S. patent system's strong preference for private ordering of IP rights has been key to its economic success. ${ }^{4}$ Its most recent significant overhaul, the 1952 Patent Act, was specifically designed to restore predictable enforcement mechanisms for patents as a push-back against the erosion of patent rights that had occurred through undermining of the patent system by overly aggressive regulation of the antitrust system. ${ }^{5}$ The 1952 Patent Act was purposefully designed to ensure that patents could better facilitate coordination among the many market participants in order to commercialize innovation. ${ }^{6}$ In keeping with this view, patents have long been enforceable with injunctions structured to preserve for patentees the option to enter voluntary transactions on terms more favorable to them than the terms that might be imposed on them by infringers in the form of damages. In turn, patent damages awards have long been structured to ensure that patentees are no worse off when their patents have been infringed than they would have been had the manufacturer selected voluntary licensing rather than infringement. The combined effect of this approach to patent remedies is that parties in the patent marketplace are encouraged to contract with each other during the time frame in which the patented technology was put to significant use.

This approach was successful in increasing the commercialization of new technologies and increasing competition. ${ }^{7}$ Participants in the patent marketplace developed a host of techniques for positively engaging with each other against the backdrop of these rules. They entered into bilateral patent licenses; they set up multilateral organizations such as SSOs with established IP policies agreed upon by all members (e.g., RAND); they set up patent pools to license technologies from several companies that are essential to implement a standard; and they sometimes designed around patented technologies or properly took on the risk that they might infringe. Carefully developed over more than a century, these rules and practices have consistently led to growth in consumer welfare, jobs, and the overall economy.

The gist of the FTC Proposal would turn this positive achievement on its head. Particularly with respect to technology incorporated into standards, the FTC flips the goal of damages calculations by seeking to ensure that infringers are no worse off for having not entered into voluntary agreements with patentees.

ion of market power in antitrust litigation. See, e.g., Ill. Tool Works Inc. v. Independent Ink, Inc., 547 U.S. 28 (2006)

${ }^{3}$ See, e.g., Kenneth W. Dam, The Economic Underpinnings of Patent Law, 23 J. Legal STUD. 247, 249

l Property Institutions in the United States, 15 J. ECON. PERSPECTIVES 233 (2001).

${ }^{5}$ See, e.g., Dawson Chemical Co. v. Rohm \& Haas Co., 448 U.S. 176 (1980) (approvingly providing extensive review of legislative history of the 1952 Patent Act and its impact on the patent-antitrust interface). For more on the 1952 Patent Act's impact on the patent-antitrust interface, see F. Scott Kieff \& Troy A. Paredes, The Basics Matter: At the Periphery of Intellectual Property, 73 GeO. WASH. L. REV. 174 (2004).

${ }^{6}$ Giles S. Rich, The Relation Between Patent Practices and the Anti-Monopoly Laws, 24 J. PAT. OfF. Soc'y 241 (1942) (five-part series of articles written by principal drafter of the 1952 Patent Act); Reiner v. I. Leon Co., 285 F.2d 501 (2d Cir. 1960) (Hand, J.) (noting "There can be no doubt that the Act of 1952 meant to change the slow but steady drift of judicial decision that had been hostile to patents"); Lyon v. Bausch \& Lomb Optical Co., 224 F.2d 530 (2d Cir. 1955) (Hand, J.) (noting “ $\$ 103$... restores the original gloss. ... [A] legislature ... must be free to reinstate the courts' initial interpretation, even though it may have been obscured by a series of later comments whose upshot is at best hazy."); Picard v. United Aircraft Corp., 128 F.2d 632, 643 (2d Cir. 1942) (Frank, C.J., concurring) (discussing the role of predictable rules for patent enforcement in helping a smaller "David" compete with a larger "Goliath").

${ }^{7}$ See infra Section IV.I. 
The central problem with the FTC's approach is that it would interfere seriously with the helpful incentives all parties in the IP marketplace presently have to contract with each other. The FTC's approach ignores the powerful incentives that it creates in putative licenses to spurn the voluntary market in order to obtain a strategic advantage over the licensor. In any voluntary market, the low rates that go to initial licensees reflect the uncertainty of the value of the patented technology at the time the license is issued. Once that technology has proven its worth, there is no sound reason to allow any potential licensee who instead held out from the originally offered deal to get bargain rates down the road. Allowing such an option would make the holdout better off than the contracting party. Such holdouts would not need to take licenses for technologies with low value, while resting assured they would still get technologies with high value at below market rates. The FTC seems to overlook that a well-functioning patent damage system should do more than merely calibrate damages after the fact. An efficient approach to damages is one that also reduces the number of infringements overall by making sure that the infringer cannot improve his economic position by his own wrong.

The FTC Proposal rests on the misguided conviction that the law should not allow a licensor to "demand and obtain royalty payments based on the infringer's switching costs" ${ }^{\text {" }}$ once the manufacturer has "sunk costs into using the technology,", and it labels any such payments as the result of "hold-up."10 The FTC focuses particular concern on "hold-up" in the context of standardized industries, arguing that "[o]nce a technology is incorporated into a standard, a firm with a patent reading on the technology can demand a royalty that reflects not only the value of the technology compared to alternatives, but also the value associated with investments made to implement the standard." 11

Posing this state of affairs as the problem-without giving serious consideration to other incentives or constraints that may prevent the pricing behavior that the FTC fears-the FTC urges courts to solve that purported "problem" by weakening the remedies for patent infringement. Thus, for damages based on an estimated "reasonable royalty" in particular, the FTC advances an argument that hinges on three main steps.

The first step in the FTC's argument is to reinterpret the "willing licensor/willing licensee" approach of the traditional "hypothetical negotiation" method of determining a "reasonable royalty." The FTC insists that the "willing licensor" requirement forbids a court in all cases from permitting any royalty that is higher than the royalty the licensee would willingly have paid in a hypothetical negotiation with the licensor, conducted with perfect information in the ex ante state of the world. In so doing, the FTC improperly overlooks the possibility that in some cases "the patentee would have rejected the maximum amount the infringer would have paid" as "inappropriate." I Instead, it confidently asserts that the innovator in the pre-standardization hypothetical negotiation "would rationally want to license the patent at the maximum amount the infringer would pay" (as opposed to declining to license). ${ }^{13}$

Unfortunately, this argument falls prey to a recurring ambiguity. It is not clear whether the FTC is asserting that this standard works as a cap on the rate this infringer would willingly have paid, or to the rate " $a$ willing licensee" would have paid. ${ }^{14}$ As we discuss later, the two prices may be very different. ${ }^{15}$

The second step in the FTC's argument would impose a direct and dramatic change in the existing law of "reasonable royalty" damage calculation by shifting the focus of such determinations onto the wrong period in time. While existing law places the "hypothetical negotiation" at the time of first infringement, the FTC urges that, in order to avoid prices inflated by "hold-up," the hypothetical negotiation should always be fixed at a time before the infringer incurred any "sunk costs" in the form of infringement-specific investments, ${ }^{16}$ regardless of when, and in what market context, the infringer actually benefited from its infringement. In the case of standardized technologies, the FTC argues that damages must always be "at the time the standard is chosen." 17 But it seems as though the FTC means just before the standard is chosen, because according to the FTC's reasoning the lock-in effect and hold-up potential are created by the act of standardization. This is particularly

\footnotetext{
${ }^{8}$ Fed. Trade Comm’n, The Evolving IP Marketplace: Aligning Patent Notice And Remedies with Competition 22 (March 2011 ) [hereinafter FTC REPORT].

${ }^{9}$ FTC REPORT at 8 .

${ }^{10} \mathrm{Id}$.

${ }^{11} I d$.

${ }^{12} I d$. at 168 .

${ }^{13} I d$.

${ }^{14} I d$. at $20,168$.

${ }^{15}$ See infra Section IV.F.

${ }^{16}$ FTC REPORT at 22.

${ }^{17} \mathrm{Id}$. at $22-23,168,193$.
} 
strange because in the real world standardization has evolved as a process that operates precisely to avoid the very hold-up problem that the FTC's new damage rule encourages.

The third step in the FTC's argument rests on the view that the maximum amount the willing licensee would have paid in its pre-investment, pre-standardization hypothetical universe is constrained at an upper equal to the "incremental value of the patented invention over the next-best alternative."18 Under that view, any price in excess of this must result from an abuse of hold-up power, which a judicial cap on damages would supposedly counteract. ${ }^{19}$

The combined effect of the FTC's three-step argument, especially within the context of standardized technologies, would be that royalties and damages awards must be kept no greater than "reasonable" as defined by the FTC's rule that focuses on "incremental value prior to standardization." Anything higher would be seen as the result of an exercise of "hold-up" power. Although the report is carefully silent on this point, its logic strongly implies that even after a voluntary license is negotiated and entered into, any allegation that the agreed price is "unreasonable" under this definition might well support private or regulatory antitrust action, attacking the enforceability of the license rate and threatening punitive antitrust penalties against the licensor. In effect rational business conduct by SSOs whose major function is to avoid hold-up problems, is treated as a false source of minor abuse and set up as an excuse for truly facilitating very pernicious abuse. Indeed, the harms from the FTC Proposal would be severe, including far more than a reduction in damage awards after a manufacturer has elected to infringe. The social costs from adopting the FTC Proposal would include decreased innovation as well as increased litigation costs from inappropriate agency actions and civil actions, and ultimately loss of value to consumers.

In summary, the FTC Proposal violates the first principle of sound administrative or legal reform: If it's not broken, don't fix it. Put differently, no one should propose major alterations in law without first identifying a systematic malfunctioning of the current marketplace. SSO organizations, with their consensually developed licensing policies, as well as licenses negotiated within the context of those policies, have proven their worth in the marketplace in view of existing patent remedies principles to an extent that is inconsistent with a call for fundamental change along the lines proposed by the FTC. Indeed, the FTC Report and Proposal are suggestive of serious examples of government hold-up, of which many have been identified and studied in the literature. $^{20}$ The FTC should instead exercise forbearance and refrain from advocating legal changes that would have the effect of holding up the IP marketplace and harming consumers.

\section{SSOs FACILITATE PRIVATE COORDINATION IN THE IP MARKETPLACE}

We begin this section by pointing out that market participants in the real world see things from a perspective that is dynamic, not static, which means that from a true, "ex ante" perspective the incentives facing all participants must be taken into account, rather than merely some of the incentives facing some of the participants at some points in time. We then review the way these dynamic incentives play out through the important role SSOs play in optimizing the entire chain of value-creating investment in the IP marketplace. We explore the way SSOs harness their powerful incentives to balance the interests of both inventors and manufacturers to develop a track record of success for consumers. We conclude our discussion in this section by exploring the way the FTC's Proposal would disrupt that role.

\footnotetext{
${ }^{18}$ Id. at $21-22$.

${ }^{19} \mathrm{Id}$.

${ }^{20}$ For more on government hold-up of firms in regulated industries, see DANIEL F. SPULBER, REGULATION AND MARKETS 603 (1989); David Besanko and Daniel F. Spulber, Sequential Equilibrium Investment by Regulated Firms, 23 RAND J. ECON., 153-70 (1992); Yossef Spiegel and Daniel F. Spulber, The Capital Structure of a Regulated Firm, 25 RAND J. ECON., 424-40 (1994); and Yossef Spiegel and Daniel F. Spulber, Capital Structure with Countervailing Incentives, 28 RAND J. ECON., 1-24 (1997). On municipalities and their opportunism towards cable firms, see Mark Zupan, Cable Franchise Renewals: Do Incumbent Firms Behave Opportunistically?, 20 RAND J. ECON., 473-82 (1989). On government hold-up and related case law, see J. Gregory Sidak and Daniel F. Spulber, Deregulatory Takings and Breach of the Regulatory Contract, 71 N.Y.U. L.REV. 851-999, (1996); and J. GREGORY SIDAK AND DANIEL F. SPULBER, DEREGUlatory TAKINGS AND THE REgUlatory CONTRACT: THE COMPETITIVE TRANSFORMATION OF NETWORK INDUSTRIES IN THE UNITED STATES (1997). For a more formal treatment of the present example of government hold-up at the interface between patents and antitrust, see, Luke Froeb, et al., Patent Hold Up and Antitrust: How a Well-Intentioned Rule Could Retard Innovation (December 3, 2010) Vanderbilt Law and Economics Research Paper No. 11-3, available at http://ssrn.com/abstract=1735587.
} 


\section{A. Standard Use of the Economic Term of Art "Ex Ante" Properly Focuses on the Time} Before All Participants in the IP Marketplace Make Decisions

In its effort to justify its recommendations, the FTC begins with a non-standard use of the term "ex ante" that focuses only on some arbitrarily selected group - infringers after they have infringed - to advance a policy agenda. ${ }^{21}$ But the term "ex ante" is used throughout the literature to refer to the situation that exists before all market actors obtain information about the state of nature, including information about their situation and those of other market actors. ${ }^{22}$ Market actors who make decisions ex ante, act based on expectations, that is before learning information about the state of nature. Indeed, the FTC's non-standard use of the term "ex ante" is also inconsistent with the connotation of "ex ante" that is sometimes used to describe the situation before parties form and invest in contractual relationships. ${ }^{23}$ The bottom line is that the true ex ante perspective necessarily applies to potential patentees and potential infringers alike. The term "ex ante" must be applied symmetrically to all economic agents that form relationships, not a select few.

From its specialized use of the term "ex ante," the FTC advocates imposing on the patent marketplace a set of rigid and uniform rules that no regular SSO participants would elect for themselves in a truly "ex ante" context. But this proposed new legal regime would generate far more litigation and uncertainty as parties rationally elect to infringe and litigate rather than negotiate with each other. This new turn of events in turn would place courts in charge of deciding the "correct" pricing for patent licenses, clogging the courts with unending disputes and preempting and impeding pricing and negotiation in the marketplace. This increased uncertainty and litigation in turn would lead to less investment in invention and its commercialization, decreasing manufacturers' options for deploying subsequent generations of technology, thereby decreasing competition and consumer choice.

A useful thought experiment asks what are the rules relating to licensing and royalties that members of a new SSO rationally would adopt in a truly "ex ante" setting: that is, at the outset of a new technology, before either inventors or manufacturers have made the investments necessary to the success of that technology. If the FTC's proposed rules would not be supported at this ex ante time even by those potential licensees (i.e., manufacturers) they are ostensibly designed to protect, it is hard to see how they could be economically optimal. Even if some manufacturers were tempted to see these rules as being in their short-term best interest, it would be apparent to them that such rules would not attract optimal investment by a potential inventor and its commercial partners (e.g., innovators, as well as their financial investors and other contracting partners). Yet to be economically viable, the rules need to attract and hold the constructive attention of the diverse set of participants in the patent marketplace. The century-old rules and practices have been shown to do just that, time and time again. Yet, the FTC's approach would displace these effective SSOs with new forms of government-aided holdup.

\section{B. The Successful Track Record of SSOs' Powerful Incentives to Balance the Interest of Inventors and Manufacturers}

The rules and norms governing SSOs are voluntary institutions created by members including both technology inventors and adopters, all of whom have a vested interest in the successful creation and commercialization of new technologies. Each potential participant in an SSO anticipates that different technologies, intellectual property rights, standards, and consumer demands, can come, and go. They also know that along the way these many changes necessarily have a range of impacts on each participant's business model as well as the overall economic success of the technology within this naturally evolved ecosystem. In addition, each SSO often has to

\footnotetext{
${ }^{21}$ See Mark A. Lemley, Ex Ante Versus Ex Post Justifications for Intellectual Property, 71 U. CHI. L. REV. 129 (2004). Lemley refers to a difference between a view of patents as providing incentives to inventors before inventions are made and a view of patents as providing incentives for patentees to control inventions after they have been made. But that is a very specialized understanding of the terms "ex ante" and "ex post" focused entirely on the perspective of specific parties in particular, rather than in terms of how decisions are made over time by all parties in the innovation market. It also does not address the school of thought that led to the present U.S. patent system, the 1952 Patent Act, which sees patents as tools for facilitating coordination rather than as direct incentives to invent or as tools for exercising control. See F. Scott Kieff, An Inconvenient School of Thought, 61 AlA. L. REV. 591 (2010), (reviewing MichaEL CARRIER, INNOVATION FOR THE 21ST CENTURY: HARNESSING THE POWER OF INTELLECTUAL PROPERTY \& ANTITRUST (2009)).

${ }^{22}$ For standard usage of the term "ex ante," see ROGER B. MYERSON, GAME THEORY: ANALYSIS OF CONFLICT, 485-486 (1991) and JOHN P. BONIN \& JEAN-JACQUES LAFFONT, THE ECONOMICS OF UNCERTAINTY AND INFORMATION, 135 (1989).

${ }^{23}$ This corresponds to the so-called "fundamental transformation" that is the focus of the well-known discussion of hold-up by Williamson. See, e.g., Oliver Williamson, The Economic Institutions Of Capitalism: Firms, Markets, Relational Contracting 61-63 (1985).
} 
wrestle with hundreds or thousands of patents, and innumerable technical choices. And unlike the settings that are most familiar to antitrust regulators-such as public utilities - the SSO setting typically involves technologies that are the recent fruit of high-risk R\&D investment and highly uncertain consumer demand.

From a true "ex ante" perspective, which is at a time before any of these complicating factors is revealed, each potential SSO participant has an interest in seeing optimal investment by all classes of participants, and so wants the SSO to adopt rules that will prevent opportunistic behaviors (even their own). SSO participants are thus highly motivated to adopt rules that, from such a true "ex ante" perspective, are seen by all interests as creating a stable environment for adequate investment by and reward to all interests. To accomplish that end, the rules must facilitate coordination among SSO members while being attentive to the full range of transaction costs including information costs, negotiating costs, and litigation costs.

If inventors and their commercialization partners reserve for themselves too large a share of the total rewards, potential licensees will be driven to look elsewhere to avoid high fees. If inventors and their commercialization partners get too small a share of the rewards, they won't be able to recoup their own investments in making and commercializing new technologies. The SSO membership is acutely aware of these fundamental tradeoffs, and therefore has strong incentives to choose the most cost-effective measures to achieve the right balance. In selecting its patent disclosure and licensing rules, the SSO membership generally operates from behind a veil of ignorance: that is, they design their rules well before any downstream party makes any of its necessary investments in basic R\&D relevant to a particular standards project, before product development, before supporting infrastructure, before marketing, and indeed before all the other ancillary SSO activities. This approach represents a true "ex ante" time frame.

SSOs relentlessly seek to maximize the likelihood that their commercial standards will gain market acceptance such that each "interest group" within the SSO is able to earn an attractive return on its subsequent investments, both in producing its own inventions, and in using the inventions of others. Those SSOs that adopt better approaches for mitigating these myriad problems are more likely to succeed than their rivals. Through this competitive process, it should not be surprising to see a host of surviving SSOs today whose rules have a record of successfully meeting in a wide variety of distinctive technological settings the needs of all classes of participants - manufacturers/licensees as well as innovators/licensors.

The success on the ground bears out the theoretical insight that hold-ups are not a serious threat to collaboration over and around standards. SSOs are not some new-fangled institution that has burst onto the scene in recent years. ${ }^{24}$ Virtually any industry that requires the interconnection of disparate products will use an SSO to reduce the transactions costs needed to bring together a diverse set of users and producers. Three such SSOs (or organizations of SSOs) recently submitted detailed comments to the FTC on its proposal. ${ }^{25}$ Each of these reported that it has never in the course of its work observed a problem of hold-up of manufacturers by owners of patents essential to its standards.

An overarching trade association for SSOs in this country is the American National Standards Institute (ANSI) whose mission is "the creation, promulgation, and use of thousands of norms and guidelines that directly impact businesses in nearly every sector." ${ }^{, 26}$ Founded in 1918, ANSI has oversight function over more focused SSOs, including those that operate in patent-intensive areas. For example, the Telecommunications Industry Association, which was first accredited by ANSI in 1988, has 70 standards committees, staffed by over 1,000 volunteers, who have generated over 3,000 standards and papers. In its letter of June 14, 2011, ANSI opposes the FTC proposal on the ground that it will place unnecessary obstacles in the path of successful standards adoptions. The Alliance for Telecommunications Industry Solutions submitted its letter to the FTC with the same message, based on close to three decades of operation in the standards space. The same is true of the American Intellectual Property Law Association, many of whose members regularly deal with IP in the SSO

\footnotetext{
${ }^{24}$ Strictly speaking, SSOs themselves are organizations, rather than institutions, but we refer to them as institutions to encourage focus on the rules that govern them and the enforcement characteristics of those rules. See Douglass C. North, Nobel Prize Lecture, available at http://www.nobel.se/economics/laureates/1993/north-lecture.html (explaining in more detail the relationship between institutions and organizations as terms of art in the field of New Institutional Economics).

${ }^{25}$ Alliance for Telecomm. Indus. Solutions, COMmEnTS ON P11-1204 at 1 (June 14, 2011) ("ATIS has not experienced the hold up problem"); INT'L COMM. FOR INFO. TECH. STANDARDS, COMMENTS ON P11-1204 at 1 (June 20, 2011) ("The current officers and staff have not been notified of any active patent 'hold-up' problems with regards to INCITS standards."); TELECOMMS. INDUS. ASSOC., COMMENTS ON P11-1204 at 4 (June 14, 2011)(“TIA has never received any complaints regarding such "patent hold-up" and does not agree that 'patent holdup' is plaguing the information and telecommunications technology (ICT) standard development processes.").

${ }^{26}$ About ANSI Overview, AM. NAT’L STANDARDS INST., http://www.ansi.org/about_ansi/overview/overview.aspx?menuid=1 (last visited Aug. 1, 2011).
} 
setting, in its letter also dated June 14, 2011. Yet there is nothing in the FTC Report that reflects the practical experience of these SSOs and their participants, or those like them. Instead the FTC prefers to rely on flawed academic critiques that place undue focus on a theoretical problem of "patent thickets," rather than giving attention to real-world reports from the SSOs themselves, which deny their occurrence. ${ }^{27}$

\section{The FTC Proposal Would Create SSOs that Would Not Work for Inventors or Manufacturers.}

The FTC Report does not offer any quantitative estimate of value-destroying breakdowns on the present system, nor any empirical basis to conclude that such breakdowns are of a frequency and magnitude that could justify radical change to a system that has enabled innumerable successfully implemented standards. As a result, it is highly unfortunate that the FTC Proposal would tilt the balance against innovators and in favor of technology adopters by substituting new rules governing royalties for patent use and remedies for patent infringementrules set by academic theory rather than by consensus of actual industry participants (as are existing SSO rules) or by statute and common-law evolution guided by innumerable real-world fact situations (as are existing rules governing damages and injunctive relief). But the FTC's nearsighted approach would remove incentives for invention and discourage private coordination needed to bring inventions to market, including the establishment of industry standards.

What is more, the FTC Proposal could not work in practice. The terms that bring parties together today are so materially and advantageously different from those that the FTC Proposal envisions that it is hard to see how these two disparate regimes could coexist. Currently, at the time that standards are being propounded, it is in the interest of no party to plant the seeds for a destructive hold-up problem down the road, and the parties have and rely on private means of preemptively avoiding the risk of later hold-up. The FTC proposal, which privileges downstream users in a manner the parties cannot contract around, thus increases the likelihood that these same downstream users will exert hold-up pressures that expropriate the patented technologies of upstream inventors and their commercial partners in ways that could easily impede the advent of new technologies.

None of this new-found uncertainty is needed. Within and through SSOs, industry participants routinely enter into complex agreements regarding compatibility and technology interoperability. These agreements operate much like miniconstitutions, in that they are usually implemented through SSO rules and are thereby multilateral, not merely bilateral, and bind all members of the SSO. If the FTC were to establish its own rigid rules to displace this existing voluntary, consensus-based, regime, the affected parties may face difficult choices about whether to invest in a technology today given the host of potential risks tomorrow. The approaches that SSOs use today also set the crucial stage that allows private parties to negotiate, when appropriate, bilateral transactions, during which specific prices are set. In this way, SSOs also facilitate bilateral interaction. But the more that technology adopters know, ex ante, that courts will give them favorable licenses ex post, the more this changed rulebook will induce downstream parties to act strategically by pulling out of the organizations that have fostered long term stability for all parties up and down the production chain. If the FTC goes further, it will arrogate first to the courts and thereafter indirectly to itself the role of effective rate-setter.

\footnotetext{
${ }^{27}$ See, e.g., Carl Shapiro, Navigating the Patent Thicket: Cross Licenses, Patent Pools, and Standard Setting, in INNOVATION POLICY AND THE ECONOMY 119 (Adam B. Jaffe et al. eds., 2000); Mark A. Lemley \& Carl Shapiro, Patent Hold-up and Royalty Stacking, 85 TeX. L. REV. 1991 (2007). While the FTC and some scholars are concerned about unlikely opportunism problems relating to potential patent thickets, patent gridlock, and patent anticommons, the more likely problems are those relating to government-created permit thickets and license Raj. See Richard A. Epstein, Heller's Gridlock Economy in Perspective: Why There is Too Little, Not Too Much Private Property, 53 Ariz. L. Rev. 51 (2010), critiquing Michael Heller, The Gridlock ECONOMY: How Too Much Ownership Wrecks MARKets, Stops InNovation, And Costs Lives (2008). See also F. Scott Kieff, On Coordinating Transactions in Intellectual Property: A Response to Smith's Delineating Entitlements in Information, 117 YALE L.J. POCKET PART 101, 106-09 (2007), building on Richard. A. Epstein, The Permit Power Meets the Constitution, 81 IowA L. REv. 407 (1995), Sunita Parikh \& Barry R. Weingast, $A$ Comparative Theory of Federalism: India, 83 VA. L. REv. 1593, 1608 (1997), and Richard A. Epstein \& Bruce N. Kuhlik, Navigating the Anticommons for Pharmaceutical Patents: Steady the Course on Hatch-Waxman 4 (Univ. of Chicago Law Sch. John M. Olin Program in Law \& Econ. Working Paper No. 209 (2d ser.), 2004), available at http://ssrn.com/abstract=536322, and critiquing Michael A. Heller, The Boundaries of Private Property, 108 YALE L.J. 1163, 1174-75 (1999) and Michael A. Heller \& Rebecca S. Eisenberg, Can Patents Deter Innovation? The Anticommons in Biomedical Research, 280 SCIENCE 698, 700 (1998).

The FTC also is overly skeptical about the role played by so-called "patent trolls," which it refers to as "Patent Assertion Entities" (PAEs). FTC REPORT at 50,60-72. While litigation tactics that are purely harassing should be condemned regardless of who employs them, critics of PAEs that are asserting cases having merit should also be mindful of the economics literature on the roles of firms as market intermediaries and the contribution of market intermediaries to transaction efficiencies. See, e.g., DANIEL F. SPULBER THE THEORY OF THE FirM: MiCROECONOMICS WITH ENDOGENOUS ENTREPRENEURS, FirMS, MARKETS, AND ORGANIZATIONS (2009) and DANIEL F. SPULBER, MARKET MiCROSTRUCTURE: INTERMEDIARIES AND THE THEORY OF THE FIRM (1999).
} 
Judicial damage awards or extensive antitrust enforcement actions would provide an easy point of entry for large firms with political clout to engage in rent-seeking behavior so well documented in the public choice literature. ${ }^{28}$

Technology inventors and adopters all understand there are risks associated with the selection of a standard. This type of risk, however, is not materially different from ordinary business risk-including possible failure in the marketplace - that most industry participants can well manage. But most technology firms cannot bear the risk that the government will place an upper bound on the return to their successful patented technologies that systematically disregards the risks of getting that technology established in the first place. Yet that is exactly what the FTC Proposal would accomplish.

Thus, the FTC Proposal would coerce SSOs to operate under rules that informed and rational industry participants would never select for themselves because they would frustrate rather than facilitate effective coordination among all involved. In contrast, current SSO practices ensure that winning technologies receive rewards that are sufficient to attract inventors as well as their commercialization partners (including manufacturers) to the marketplace in the next innovation cycle

\section{THE SUFFICIENCY OF EXISTING PRIVATE ORDERING SOLUTIONS TO MITIGATE HOLD- UP RISK, INCLUDING LICENSES, REPUTATION THROUGH REPEAT PLAY, AND RAND COMMITMENTS}

In this section, we explore in more depth the mechanisms underlying several of the key tools that are used successfully in the IP marketplace to significantly mitigate hold-up risk. We begin with the core definitional point: "hold-up" is a term of art in the economic literature that is well understood by sophisticated participants in the IP marketplace. Because no reasonable party in the patent marketplace is surprised to face large numbers of patents, or new patents constantly arriving on the scene, these private parties have long successfully employed these and other private ordering solutions to sufficiently mitigate hold-up risk rather than looking to the government to impose new rules on the marketplace for regulating the use of these patents. We discuss several particular examples of these ordering solutions: negotiating licenses ex ante, relying on reputation effects in a repeat play setting, and commitments to license patents on reasonable and non-discriminatory (RAND) terms. We then point out that these private ordering solutions should be expected to work much better than the government approach that the FTC seeks to impose because private parties have significant informational advantages over government actors at the FTC and in the courts. We conclude the discussion in this section by showing some ways in which the FTC is trying too hard to find problems with well-functioning private ordering solutions in the IP marketplace.

\section{A. Participants in the IP Marketplace Typically Solve "Hold-Up" Problems Through} Regular Direct Interaction With Each Other

The term "hold-up" has a very precise definition in the economic literature and it is important to first set that definition within its broader theoretical context. ${ }^{29}$ The concept of "hold-up" has been extensively elaborated on in work by the Nobel Prize-winning economist Oliver Williamson, who also referred to it as "opportunism" which he defines a "self-interest seeking with guile." 30 The presence of the term "guile" in this definition is key, and contemplates both that the perpetrator of the behavior acts badly and that the victim is unaware.

Farrell, et al., define the term differently, omitting the requirement of "guile":

In very broad terms, opportunism or hold-up arises when a gap between economic commitments and subsequent commercial negotiations enables one party to capture part of the fruits of another's investment, broadly construed. Hold-up can arise, in particular, when one party makes investments specific to a relationship before all the terms and conditions of the

\footnotetext{
${ }^{28}$ Stephen Haber et al., On the Importance to Economic Success of Property Rights in Finance and Innovation, 26 WASH. U. J.L. \& POL'Y 215, 236-40 (2008) (providing general review of institutional details that can make property rights operate "at their best" or "at their worst").

${ }^{29}$ Regrettably, some confusion surrounding the term "hold-up" may be caused by the extensive citation in the economic literature to a purportedly canonical example that has been proven factually incorrect. See, Ronald Coase, The Conduct of Economics: The Example of Fisher Body and General Motors, 15 J. ECON. \& MANAgement Strategy, 255 (2006), citing Ramon Casadesus-Masanell \& Daniel F. Spulber, The Fable of Fisher Body, 43 J. L. \& ECON., 67 (2000).

${ }^{30}$ See e. e.g., Oliver Williamson, The Economic Institutions Of Capitalism: Firms, Markets, Relational Contracting 61-63 (1985). A recent survey finds 900 empirical articles citing to this work, and the number is growing (http://www.bepress.com/bap/vol10/iss1/art1/). The theoretical literature is probably even larger.
} 
relationship are agreed. Hold-up generally leads to economic inefficiency that contracting parties, and courts interpreting contracts, often try to avoid. ${ }^{31}$

But even Farrell et al.'s definition of the term does not extend to situations that merely enable the first party to retain a greater proportion of the fruits of its own investments. Nor does it include in the class of "hold-ups" every instance in which the second party fails to fully recover all investments that it may make that are specific to the relationship. On the contrary, not all investments succeed in creating value, so that it is customary for the second party to reasonably assume some risks that some of its specific investments will be lost. It would be strange and counterproductive to adopt a definition and rule against hold-up that makes the first party supply complete insurance for all risks born by the second party. That coercive redistribution of risk would unduly saddle inventors with even ordinary business risks within the control of manufacturers, as well as raise a host of moral hazard problems.

Yet even though the FTC repeatedly cites to Farrell, et al., ${ }^{32}$ it actually conducts its analysis and argument based on a third definition of hold-up that doesn't require capturing the fruits of another's investment. Thus, the FTC Report provides this definition of "hold-up:"

a patentee's ability to extract a higher license fee after an accused infringer has sunk costs into implementing the patented technology than the patentee could have obtained at the time of design decisions. ${ }^{33}$ [If switching costs result in a] reasonable royalty ... higher than it would have been at the time of the design choice, [then this is] "hold-up" [that] overcompensates patentees compared to the economic value of the invention. ${ }^{34}$

This peculiar FTC definition of hold-up is not only very different from the definitions offered by Williamson and in Farrell, et al, it also is so arbitrary as to be not useful. The major reason why the hold-up problem typically is solved is that the two parties have already dealt with each other prior to its possible occurrence. In contrast, the holdout problem is one that arises between strangers who have had no course of dealing with each other. Thus, suppose someone wants to build a new factory on the top of a hill, whose only connection to a key railroad is over a neighbor's plot of scrubland. ${ }^{35}$ At this point, the factory owner would only commit to build that structure if it first obtained all necessary easements over the scrubland to prevent any holdout problem down the road. In this case, moreover, the potential factory owner would be prepared to play off one potential site against another to drive down the price of the needed easements. Indeed, in most settings the scenario plays out the other way, for landowners who seek to encourage the location of new factories often present them in advance with a packet of easements and related benefits that negate the holdout problem before it starts.

The situation is the same with IP rights, for the advance knowledge of a potential holdout risk leads parties to negotiate mutually acceptable solutions prior to its occurrence. The success of those negotiations is aided by the set of tools that patent law has developed to mitigate holdout risks, such as the disclosure requirements for issuance of a valid patent on the front end, and well chosen rules regarding remedies after patent infringement on the back end. ${ }^{36}$ In addition, in the context of standardized technologies, some SSOs provide an additional early source of information about potentially needed licenses in the form of requirements for public disclosure of potentially essential patents.

\section{B. The Effectiveness of Bilateral Licensing}

Manufacturers can and do engage in bilateral patent licensing before seriously investing in patented technology, both in settings in which SSOs are deployed, and those in which they are not. For example, in its recent submission to the FTC surrounding the present Hearings, Qualcomm reports that it regularly grants licenses prior to the adoption of a standard, and has never encountered a case in which a patent-holder has refused a request to

\footnotetext{
${ }^{31}$ Joseph Farrell et al., Standard Setting, Patents, and Hold-up, 74 ANTITRUST L.J. 603, 603-04 (2007).

${ }^{32}$ See FTC REPORT at 139, 191-92, 227, 234.

${ }^{33}$ FTC REPORT at 191 n. 61

${ }^{34} I d$. at 22

${ }^{35}$ See, Strickley v. Highland Boy Gold Mining Co., 200 U.S. 527 (1906). See also, Clark v. Nash, 198 U.S. 361 (1905), where a taking was allowed for irrigation ditch that was "absolutely necessary" to service a plot of land that was otherwise arid and valueless. The use of eminent domain eliminates the holdout problem. But the requirement of just compensation for the value of the property taken guards against the risk of expropriation.

${ }^{36}$ See discussion infra Section IV.
} 
negotiate a pre-standardization license. ${ }^{37}$ In a variation on this theme, patentees like Qualcomm have demonstrated a track record of reaching deals with licensees over existing technologies that also embrace future technology standards. ${ }^{38}$ These contractual arrangements for future technologies go a long way towards mitigating potential risk of hold-up, and the licensor's willingness to enter into such open-ended licenses covering future standards gives some indication that the patent-holder preferred the licensing option to preserving some potential opportunity to hold up the manufacturer at some future date.

Nor, in the large majority of cases, will there be any difficulty in identifying - even prior to the adoption of a standard - the counterparties from which a manufacturer will need a license. Because most licensing relating to complex technologies is conducted on a portfolio basis, only a small number of players need to be contacted to reach the lion's share of the relevant pool of patents. Although manufacturers may not know instantly precisely which patents are available for licensing, keeping patent portfolios hidden from potential revenue-producing users is a losing game for any patentee. Patents are wasting assets that cost their owners a great deal to enforce during their effective term. Accordingly, these patentees have powerful incentives to make their patent portfolios easily known to technology adopters, both large and small. In addition, many SSOs directly address the potential infringer's informational problem by adopting rules that affirmatively require members to publicly identify patents that are or may be essential to standards under development. Thus, especially in those areas of technology that are the focus of the FTC Report's concern with SSO hold-ups, the proper licensor for most patents in a given field can readily be found.

With all that said, while some manufacturers do move to obtain licenses before making serious investments in the patented technology, evidently some do not, even for those patents covering technologies they expect to become necessary. Yet it is hard to see why a change in the rules is either necessary or prudent to protect these "late movers."

In fact, those who do not negotiate a license ex ante can generally be divided into four sub-categories, not one of which is in the kind of desperate straits that would properly justify the forcible interventions outlined in the FTC's Proposal. Each of these four groups is summarized below:

1. The first group comprises those parties who did not anticipate needing the patented technology and turn out to be correct. For these, no hold-up can occur.

2. The second group comprises those parties who did not anticipate needing the patented technology and who turn out to be wrong, so any hold-up potential is caused by their own failure to plan correctly. The FTC Proposal would eliminate the incentives that the current practices supply to all manufacturers to engage in careful planning so as to obtain needed rights.

3. The third group includes manufacturers who anticipate that they may need a license, but conclude based on experience with industry practices that they will not in fact be exposed to a "hold up" risk. These parties thus conclude that they will not be unduly disadvantaged if they wait to negotiate a license until a later time. Accordingly, they rationally decide to postpone devoting resources to that licensing process until their need for a license is certain. The very existence of this group is a striking evidence of how the FTC vastly overestimates the hold-up problem that drives its entire agenda in this area.

4. The fourth group comprises those who are good at planning, but who direct their planning based on the prospects of getting a government actor like the FTC to intervene on their behalf, presumably with an eye towards obtaining better terms than those available through a voluntary ex ante negotiation.

In summary, FTC Report wrongly suggests that market failures such as imperfect information and differing valuations are the only two reasons why parties fail to strike efficient patent licensing deals up front. ${ }^{39}$ But sometimes it is efficient for a deal to not get done. Sometimes the technology will not be used. On other occasions the infringer is so inefficient that it can't afford to pay the market rate. Furthermore, the knowledge that infringement may offer the downstream user its lowest-cost option under the FTC's proposed damage rules, would significantly increase incentives for all future manufacturers to become part of this ever-expanding latter group, who focus on currying government favor rather than entering licensing agreements. The situation will

\footnotetext{
37 Qualcomm, INC., COMments ON P11-1204 at 8 (June 13, 2011) ("Qualcomm has not encountered a situation in which "late" identification of particular essential patent claims (or applications) by an SSO member that has given a categorical RAND commitment has altered the price of, or negotiating dynamic for, a license.").

${ }^{38}$ See Appendix A, which sets forth a set of representative excerpts from existing Qualcomm license agreements that relate to future technology standards.

${ }^{39}$ FTC REPORT at 170.
} 
only get worse if courts refuse to issue patentees injunctions against infringing conduct under $e B a y v$. MercExchange, ${ }^{40}$ a prospect that we do not discuss in this paper. ${ }^{41}$

\section{Restraining Opportunism with Reputation and Repeat Play}

One reason why "late movers" in the third group, mentioned above, are willing to do business without an ex ante license is that they calculate the risk of hold-up to be low precisely because technology adoption is an almost endlessly repeated game. In the case of cellular phone technology, the $3 \mathrm{G}$ standard was technically developed while $2 \mathrm{G}$ royalties were being negotiated and/or paid; and $4 \mathrm{G}$ is now being developed while $3 \mathrm{G}$ licenses are being negotiated or paid. In other words, industry participants do at least three activities simultaneously. They cooperate with each other (or not) in SSO technology committees to develop the next standard; they negotiate the next license; and they pay royalties under the last license. Any participant perceived as behaving "badly" in the licensing context is likely to find few allies and face many difficulties when it seeks to promote its new technologies for inclusion in future standards. In this highly interlaced world, across players and across time, reputational constraints cut deeply. Furthermore, because the same major players show up repeatedly in many different settings, the power of reputation exerts a significant multiplier effect that restrains patentees from acting opportunistically. Qualcomm, for example, is a member of over $80 \mathrm{SSOs}^{42}$ If a patent-rich party were to behave "badly" in one context, it will quickly pay a reputational price in unrelated standards markets. This powerful multiplier effect constrains all but the peripheral set of one-shot players.

\section{RAND Commitments and the Private Market}

In addition to direct, bilateral licenses, groups of market participants also make widespread use of SSO rules applicable to all member parties. In these settings, patentees agree in advance to commit to offering licenses on RAND terms as a condition of including a patented technology in the standard. ${ }^{43}$ Such RAND commitments give potential adopters of a technology the assurance of knowing that the patented technology necessary to implement the standard will at least be available for licensing on terms that will not strongly disadvantage them as compared to their similarly-situated competitors. In this sense, SSOs have already adopted by private agreement a flexible but important set of limitations on pricing that responds to market incentives, not government dictates.

It is true that SSO rules consistently fail to define "RAND" according to any precise formula. But because this is the consensus result of the competitive evolution of SSO rules we have discussed earlier, it is appropriate to take as a first hypothesis that this flexibility in the concept of RAND is a strength, not a weakness. One size rarely fits all, and the use of RAND terms does not obligate each patentee or SSO to ensure that every licensee receives identical terms.

There are many reasons why identical terms will not be appropriate in all cases. In some instances, some licensees are in a position to supply cross-licenses of varying value to the licensor. In other instances licensees are in a position to engage in some other form of valuable commercial cooperation. One type of cooperation commonly explored involves a commitment to make market-expanding investments. Another involves a commitment to engage in risk-sharing with the licensor through an up-front payment. Yet another involves a commitment to return valuable information to the patentee. Each of these forms of value may be balanced by a lower cash license fee or royalty rate.

In addition, some licensees may well sign on sooner when the technology is riskier and the value of the license less certain (e.g., before a standard is developed). These early sign ups provide valuable market validation as well as early liquidity for the innovator. In return, they may receive a lower nominal price, just as those individuals who purchase condominiums when they are first put on the market often receive lower prices than buyers who purchase at the end of the sales cycle. In other cases, it may well be that the precise terms for

\footnotetext{
${ }^{40}$ eBay, Inc. v. MercExchange, LLC, 547 U.S. 388 (2006).

${ }^{41}$ The traditional equitable analysis within the test for injunctions wisely asked only whether someone otherwise entitled to an injunction should not get one, in the judge's discretion, in light of a hardship on the defendant that could be shown to be grossly disproportionate. See Richard A. Epstein, A Clear View of The Cathedral: The Dominance of Property Rules, 106 YALE L. J. 2091, 2102 (1997); Herbert F. Schwartz, Injunctive Relief in Patent Infringement Suits, 22 U. PA. L. REV..1025, $1045-46$ (1964); 42 AM. JUR. 2d Injunctions, § 35 (2005).

${ }^{42}$ QUALCOMM, InC., COMMENTS ON P11-1204 at 2 (June 13, 2011)

${ }^{43}$ See Mark A. Lemley, Intellectual Property Rights and Standard-Setting Organizations, 90 CAL. L. ReV. 1889 (2002) (showing that SSOs often adopt RAND agreements).
} 
use may vary significantly depending on the particular uses to which the new standard is put. ${ }^{44}$ These are just some of the main reasons why maintaining flexibility around a RAND commitment is hugely beneficial for both patentees and manufacturers, and ultimately for consumers.

At the same time, the flexibility of a RAND commitment does not mean that it is meaningless. RAND has been the subject of legal assertion, both offensive (Nokia v. Qualcomm) and defensive (Nokia v. Apple). ${ }^{45}$ Although these complex cases settled before court decisions were reached - the common result in commercial disputes between sophisticated industry participants with wide range of business relationships and potential relationships - the mere risk of adjudication is sufficient for RAND to influence negotiations of license terms.

Private SSOs thus maintain for all players the flexibility to strike deals capable of accommodating a wide range of business models (e.g., vertically integrated and non-integrated organizations), a host of private objectives (e.g., short term and long term planning horizons, low and high risk tolerance), and a variety of production technologies and operating costs. They also hold open the prospect of recontracting down the road if the initial set of terms no longer works for the mutual advantage of all parties.

\section{E. Addressing the Risk of Reverse Hold-Up with SSO Rules}

Unlike the FTC Proposal, existing SSO rules also mitigate the risk that manufacturers may use the standardization process to hold up innovators who have already "sunk" their R\&D costs, by demanding from innovators low royalty terms as a condition for supporting inclusion of particular technology in a standard. In fact, some major SSOs have rules that prohibit the discussion of licensing terms within technical standardization deliberations and that require standardization decisions to be made based on technical considerations. ${ }^{46}$ This is not to say that participants may not be biased against inclusion of technology belonging to "bad actors," as discussed above. It does, however, appear to prevent anything like an "auction for inclusion," which could facilitate hold-up of innovators by manufacturers after the innovators have made large investments in their technology development.

Both innovators and manufacturers receive another layer of protection within the voluntary SSO system in that the SSO process (unlike the FTC's proposed mandates) is not exclusionary. Any industry participants that do not like the balance struck by a given set of SSO's rules are free to advocate that the SSO change its rules, or to start a competing SSO working under different rules. The extent to which a significant number of SSOs, with stable rules persist over time suggests that those rules and SSOs generally strike a balance that is

\footnotetext{
${ }^{44}$ There is wide consensus that RAND does not, and should not mean "same terms for everyone," but instead mean something closer to "similarly situated licensees are entitled to similar terms," but that's about it. See Roger G. Brooks \& Damien Geradin, Taking Contracts Seriously: The Meaning of the Voluntary Commitment to License Essential Patents on "Fair and Reasonable" Terms at 19, Working Paper (Mar. 12, 2010), http://papers.ssrn.com/sol3/papers.cfm?abstract_id=1569498. Some considerable flexibility in terms (including rates) is industry standard. On the other hand, we suspect that substantial (e.g. 2-fold) price discrimination merely to take maximum advantage of the higher demand of some licensees, without some additional counterbalancing value flowing to the licensor, would be widely considered inconsistent with a RAND commitment. To use the language of general public utility regulation, cost-based price discrimination is needed to encourage efficient utilization. Demand-based price discrimination is more difficult to evaluate. On the one hand, it allows for rent extraction. On the other hand, the higher rates charged to higher demanders may soak up a larger fraction of fixed costs which allow lower demanders to participate in the market. We do not address these complications here. Certainly we do not want to suggest a belief that there is complete freedom to price discriminate in the face of a RAND commitment.

${ }^{45}$ For example, Nokia and Qualcomm had a huge and intense litigation over RAND in 2007-08 that settled the morning of trial. Both of those parties had large cellular patent portfolios that made sense to cross-license, which they are reported to have accomplished through a lengthy agreement. According to public reports, the settlement also included a sale of a large patent portfolio from Nokia to Qualcomm, and cleared the way for the parties to enter into other mutually advantageous, complex, and ongoing business relationships. See, e.g., Nokia Press Release (Feb. 17, 2011); Qualcomm Press Release (Feb. 17, 2011); Paul Taylor, Nokia and Qualcomm to Develop New $3 G$ Handsets, FT.COM (Feb. 17, 2009); W. David Gardner, Nokia, Qualcomm Team up to Deliver Symbian Devices, INFORMATIONWEEK (Feb. 17, 2009); Elizabeth Woyke, Nokia And Qualcomm: Happy Together, ForBeS.COM (April 21, 2009); Nokia picks Qualcomm for Windows phone, Seeks Others, REUTERS (May 20,2011). Such success in striking a deal to resolve even a highly heated dispute reveals a great deal about the relative power of private ordering constraints including the recognition by both parties that they each benefit from smooth repeat interactions since they "live in the same neighborhood" compared to the power of factors that are the focus of the behavioral economics literature, such as irrational cognitive bias and animosity. If the real-world relative impact of these factors had cut the other way, then Nokia and Qualcomm would not have been successful in moving very quickly from all-out war to identifying and seizing joint business opportunities.

$46 \quad$ See, e.g., ETSI Guide on IPRs, $\S \S \quad 2.3, \quad 4.1 \quad$ (Nov. 27, 2008), available at http://www.etsi.org/WebSite/document/Legal/ETSI_Guide_on_IPRs.pdf (last visited Aug. 1, 2011); Guidelines for Implementation of the ANSI Patent Policy, § III.B (Feb. 2011), available at http://publicaa.ansi.org/sites/apdl/Documents/Standards Activities/American National Standards/Procedures, Guides, and Forms/Guidelines for Implementation of ANSI Patent Policy 2011.pdf (last visited Aug. 1, 2011); VITA Standards Organization—Policies and Procedures, § 10.3.4, available at http://www.vita.com/home/VSO/vso-pp-r2d6.pdf (last visited Aug. 1, 2011).
} 
acceptable to market participants. At the same time, the extent to which new rules and new SSOs are adopted similarly suggests that market participants are able to implement superior alternatives when established patterns no longer serve well.

\section{F. The Significant Informational Advantages of Private Parties over Governmental Actors}

The frequent use of this powerful toolkit of private arrangements is hard to reconcile with the FTC's premise that SSO participants make systematic errors over licensing arrangements that disadvantage manufacturers in ways that require forcible intervention and correction by non-participant courts or regulators. Even granting that the current balance of rights, incentives and remedies will not produce perfectly efficient results (no process can), courts and regulators certainly lack the expertise and detailed technological knowledge, let alone the resources and time, to intervene and control the extensive private negotiations occurring at the technological frontier. Governments have proven repeatedly that they lack the expertise and skill to pick and appropriately price technology winners. Only private industry can form the web of relationships necessary to conduct the difficult experiments needed to fund, develop, and test new products and manufacturing processes in the laboratory and in the marketplace. In light of the extraordinary delicacy involved in license negotiations over complex standards, regulators lack the knowledge and resources to replicate private negotiations in general. No one can seriously imagine the government sensibly immersing itself in the details of every construction project. Yet, that just what the FTC Proposal invites courts and competition enforcement agencies to do with regard to some of the most complex cooperative efforts and technologies in our modern economy.

\section{G. The FTC Overstates Problems with Private Ordering Solutions}

The FTC appears to believe that private awareness of both holdout and hold-up risks in general does not motivate and enable these parties to adequately address these risks for patented technologies in particular, whether through SSO rules or bilateral negotiations. This view may stem from a belief that because they are intangible, defined by mere words, patents fail to give notice of the boundaries of the property rights they create. ${ }^{47}$ But patent rights are by no means unique in being "intangible," and parties routinely contract successfully regarding intangible rights. For example, many property rights in land are intangible, such as easements, and yet market actors are able to contract over them and plan around them at reasonable cost without placing undue burdens on competition. Indeed, unlike property rights in land, which are ordinarily recorded at countless offices across the country using a range of standards for language and form, and governed by disparate state laws, patents are centrally filed and searchable online for free using consistent forms and a single body of case law about interpretation.

Unfortunately, this view ignores or dismisses the explicit requirement of the current patent law, which requires an extensive disclosure that publicly teaches and describes the claimed subject matter as a precondition for issuance of a valid patent. These disclosures reveal the best modes known to the inventor, and they are definite enough to give other inventors adequate notice about the boundaries of any given patented technology. ${ }^{48}$ It is noteworthy that in each of the high profile cases so often held up as examples of "holdout"-such as RIM, eBay, and Microsoft v. $i 4 i^{49}$ - the patents in those cases were judged by the courts to have satisfied every one of these disclosure requirements despite extremely well-funded litigation teams making every conceivable invalidity argument. Throughout Patent Office reexaminations, the federal court trials, and federal court appeals, including to the Supreme Court in some of these cases, these patents were determined to give adequate notice. What is more, in Microsoft v. $i 4 i$ the patent was sufficiently clear that the infringement was found to have been willful. ${ }^{50}$ One can't willfully violate rights whose boundaries are not understood.

Further, at least with respect to the great bulk of patents essential to the type of technology-intensive standards that appear to concern the FTC most, the "notice" problem is a non-issue when it comes to licensing. Because the vast majority of patents essential to such standards are held in portfolios of known participants in

\footnotetext{
${ }^{47}$ See, e.g., James Bessen \& Michael J. Meurer. Patent Failure: How Judges, Bureaucrats, and Lawyers Put InNOvators at RISK 29-72 (2008).

${ }^{48} 35$ U.S.C. § 112, paras. 1-2 (setting forth the disclosure requirements of patent law known as "enablement," "written description," "best mode," and "definiteness.").

${ }^{49}$ NTP, Inc. v. Research in Motion, Ltd., 418 F.3d 1282 (Fed. Cir. 2005); eBay, Inc. v. MercExchange, LLC, 547 U.S. 388 (2006); Microsoft Corp. v. i4i Ltd. Partnership, 131 S.Ct. 2238 (2011).

${ }^{50}$ i4i Ltd. Partnership v. Microsoft Corp., 598 F.3d 831, 858-60 (Fed. Cir. 2010); aff'd sub nom Microsoft Corp. v. i4i Ltd. Partnership, 131 S.Ct. $2238(2011)$.
} 
the relevant industry, and are licensed on a portfolio basis, manufacturers often know with near certainty which current patent holders to approach for licenses even if they do not know with precision what the boundaries are of every single patent within that large portfolio.

The FTC policy first tries too hard to contain the low risk of hold-up by licensors and then compounds its mistake by treating licensees as a class entirely populated by victims. The risks of this approach are illustrated by the long running controversy over alleged exercise of hold-up power by Rambus over memory chip manufacturers in connection with its participation in an SSO. ${ }^{51}$ Ultimately the federal appellate courts rejected each theory of hold-up by Rambus as not supported by the facts. ${ }^{52}$ That conclusion implies that the extensive costs of those proceedings - on both the government and the market - were spent for no good purpose. It was the government's other costs spent proving that the complaining DRAM manufacturers-Hynix and Infineonhad themselves engaged in extensive pricing fixing, that were productive in catching behavior that was so bad that it generated criminal charges involving fines now totaling over half a billion dollars and jail sentences for several of the conspiring executives. ${ }^{53}$

\section{THE FTC'S ILL-CONCEIVED AND INEFFICIENT PROPOSED CHANGES TO LONG-} ESTABLISHED DAMAGES RULES

Our discussion in this section details a number of ways in which the FTC Proposal would make important, but ill-advised, changes to the rules governing the damages that are imposed when parties infringe. As more fully detailed below, these prescriptions are systematically and seriously misguided for multiple reasons.

\section{A. The FTC's Improper Approach to Damages Would Ensure that Infringers Pay No More Than Licensees}

One of the central prescriptions of the FTC's Report is that courts should change their approach to calculating damages for patent infringement, both in general, and with particular reference to infringement of patents subject to RAND commitments. Among other things, the FTC urges the following:

Courts should apply the hypothetical negotiation framework to determine reasonable royalty damages for a patent subject to a RAND commitment. Courts should cap the royalty at the incremental value of the patented technology over alternatives available at the time the standard was defined. ${ }^{54}$

Indeed, the FTC argues that the innovator in the pre-standardization hypothetical negotiation "would rationally want to license the patent at the maximum amount the infringer would pay" (as opposed to declining to license), and notes that this figure necessarily sets the upper bound on the royalty rates to which the parties would actually agree. ${ }^{55}$ The FTC further points out that a reasonable royalty damage measure for patents subject to a RAND commitment is "the hypothetical negotiation amount" in a negotiation conducted "at the time of setting the standard," which presumably will be lower than that upper bound. ${ }^{56}$

The combined effect of these prescriptions would be that the blithe infringer - the infringer who for any reason falls short of "willful"-is to pay no more, if identified, sued, and defeated, than he would have had to

\footnotetext{
${ }^{51}$ The Rambus case involved four technologies that were patented by Rambus and that were included in a memory chip standard developed by an SSO of which Rambus was a member. Rambus left the SSO after it became apparent that the SSO's required licensing terms were not compatible with Rambus's intended terms. Litigation and an FTC complaint ensued. The administrative law judge dismissed the FTC complaint, but the Commission reversed, holding that Rambus willfully engaged in misrepresentations. The D.C. Circuit Court of Appeals set aside the Commission's orders. Rambus Inc. v. F.T.C., 522 F.3d 456, 459-62 (D.C. Cir. 2008).

${ }^{52}$ Rambus Inc. v. F.T.C., 522 F.3d 456, 468 (D.C. Cir. 2008) (citing Rambus Inc. v. Infineon Technologies AG, 318 F.3d 1081,1102 (Fed. Cir. 2003) (deciding that the patentee did not commit fraud or breach of contract)) (holding that "the Commission failed to demonstrate that Rambus's conduct was exclusionary, and thus to establish its claim that Rambus unlawfully monopolized the relevant markets.").

${ }^{53}$ See, e.g., Press Release, U.S. Dept. of Justice, Samsung Agrees to Plead Guilty and to Pay $\$ 300$ Million Criminal Fine for Role in Price Fixing Conspiracy, available at http://www.justice.gov/opa/pr/2005/October/05_at_540.html (last visited Aug. 1, 2011):

Samsung Electronics Company Ltd. (Samsung), a Korean manufacturer of dynamic random access memory (DRAM) and its U.S. subsidiary, Samsung Semiconductor Inc., have agreed to plead guilty and to pay a $\$ 300$ million fine for participating in an international conspiracy to fix prices in the DRAM market, the Department of Justice announced. Samsung's fine is the second largest criminal antitrust fine in U.S. history and the largest criminal fine since $1999 . .$. Including today's charge, three companies and five individuals have been charged and fines totaling more than $\$ 646$ million have resulted Id. from the Department's ongoing antitrust investigation into price fixing in the DRAM industry.

${ }^{54}$ FTC REPORT at 194.

${ }^{55} \mathrm{Id}$. at 168,168 ก. $37,187$.

${ }^{56}$ Id. at $168,193$.
} 
pay if he had in fact negotiated a license at the time the standard was set. The situation is difficult enough if the patentee is in a position to identify and pursue, often at great cost, the large number of infringers. But these assumptions ignore the high costs in the detection and enforcement of these rights, especially if operating under FTC rules that artificially depress the expected returns from litigation. The inevitable slippage in the damage system, combined with the risks of error inherent in any system of litigation, would invite downstream manufacturers to adopt a strategy of willful ignorance under which they would to steer clear of high damage awards while advancing their own businesses on the backs of technologies invented and paid for by others.

\section{B. The Harmful Effects for Consumers of the FTC's Measure of Damages}

The FTC approach to damages defines the "reasonable" damages to be that price which would be arrived at a moment the FTC misleadingly labels as "ex ante" when the licensee presumably has maximum bargaining power over the innovator since the licensee has made no investment in the technology while the licensor has made considerable investment in developing the technology. The "reasonable" price suggested by the FTC does not reflect in any way the bargains that would be arrived at in the real marketplace, in which participants decide to negotiate licenses - and indeed to enter the market - at a wide variety of times, for a variety of reasons, and facing a variety of risks and opportunities. If the FTC's bargain prices were always available to infringers through the courts, or worse yet were used as a standard to accuse negotiated license terms retroactively of being "unreasonable," the result would be the destruction of private bargains and the generation of governmentsponsored hold-up that would substantially reduce the returns to innovators and adopters alike.

The FTC Proposal does not serve the interests of consumers. It is precisely the reasonable expectation of supracompetitive profits that spurs both inventors and their contracting partners in commercialization to open up new technological fields and develop new markets. In these continually cutting-edge markets, the best way to constrain monopoly profits is not to transfer pricing to courts or enforcement agencies, but to develop a legal regime whereby the rapid introduction of a second product in a given field offers some measure of competition to the earlier entrant. The FTC's below-market pricing systems make it all the more likely to postpone the next wave of innovation. A sound system of market returns depends on private coordination among inventors, technology adopters, and customers in ways that adjust flexibly to the distinctive characteristics of a given technology and to continued technological change. Arbitrary regulatory pricing formulas cannot hope to replicate such market agreements between inventors, adopters and customers. Rather, their major impact would be to throw the utility and validity of these contractual arrangements into doubt.

\section{Using Damages to Encourage Private Ordering Rather Than Infringement}

The FTC's approach to damages sets the wrong goal. It is neither possible nor desirable to tailor and cap the measure of damages so that implementers are indifferent between infringement and taking a license. On the contrary, one of the key functions of a damage remedy is to induce rational actors to take the necessary steps to identify relevant patents and acquire voluntary licenses.

Compared to industry participants, courts and regulators are severely lacking in the information and resources necessary to value and structure transactions over complex innovation within rapidly evolving industries, and will chronically do it badly, thereby introducing severe uncertainty and mis-incentives into the cycle of investment in $\mathrm{R} \& \mathrm{D}$, product development, and marketing. The difficulties of setting ideal damage rules with patented technologies are far greater than they are for simple cases involving conversion of typical items of personal property. In virtually all contexts, research and development $(R \& D)$ is both a costly and a risky business plagued by an irreducible level of randomness. The outcomes of R\&D are not known in advance. The uncertainty present in the process of scientific and technological discovery is one of the most significant attributes of inventive activity. There is no mechanical connection between investments and outcomes in R\&D because of the uncertain nature of inventive activity. ${ }^{57}$ Accordingly, technology prices cannot be accurately established through arbitrary price regulation, as there is no well-defined "rate base" of the sort that can be put together (and, even then, only with difficulty) in public utility regulation in such industries as natural gas or electric power. ${ }^{58}$ Indeed, even in the traditional regulated industries, price-setting through governmental mechanisms proved so unsuccessful and inflexible that deregulation of prices has generated manifest consumer

\footnotetext{
${ }^{57}$ See Frank KNIGHT, RisK, UnCERTAINTY, AND Profit 20 (1921) ("It will appear that a measurable uncertainty, or 'risk' proper, as we shall use the term, is so far different from an unmeasurable one that it is not in effect an uncertainty at all.").

${ }^{58}$ For a summary of the difficulties, see Duquesne Light Co. v. Barasch, 488 U.S. 299 (1989).
} 
benefits in such diverse industries as telecommunications and the Internet, wholesale and retail electric power, natural gas, trucking, railroads, and airlines. Against this record, to steer the pricing of a substantially increased proportion of intellectual property into the hands of courts by redefining infringement damage awards is not an acceptable policy.

Private ordering solutions create value that courts or regulators cannot. Patent license contracts related to industry standards are often complex because they reflect the benefits of cooperation between the parties and contain elaborate value protection mechanisms. That is why these patent contracts usually take many pages of single-spaced text. If they were merely focused on the dollars payable in the event of breach, they could be completed in a single sentence that contains the patent number and a damage schedule that assigns a dollar amount to each level of infringement. But court and agency options for regulating value are essentially limited to just that type of narrow tool kit- the single damages award. In addition, a negotiated license also will provide predictability - at an earlier stage than will litigation - thereby enabling the parties to seek investment, set up firms, formulate strategic plans, generate jobs, and make routine business decisions in the knowledge that they can rely on the expectations created by the license. Neither courts nor regulators can discharge any of these tasks.

Litigation imposes large costs compared to those triggered by private contracting. The costs imposed on the court system are obvious, and it is not apparent why taxpayers should subsidize the cost of allocation of intellectual property rights between businesses. Litigation rather than voluntary contracting also imposes large costs on the patent owner, some obvious and some less so. As is well known, the direct costs of patent litigation are commonly very large. Less visible costs, including the consumption of management attention, the unavailability of revenues until the conclusion of the litigation, the uncertainty of outcome inherent in litigation, and resulting customer reluctance to commit to product offerings, may in fact impose equal or greater burdens. Likewise, all downstream manufacturers are likely to suffer many of these categories of costs. Private contracting prior to infringement avoids all of them, at the far lower business cost of identifying potential licenses and contracting over them.

This catalogue of difficulties in litigation does not deny that courts will have to do the best they can in order to estimate damages in a routine patent infringement case today; of course they must. But it is to say that the overall incentive structure should motivate implementers to identify, negotiate, and take needed licenses in a timely fashion, rather than to engage in widespread infringement, which allows them to use patent adjudication to set their resulting obligations to the patent owner. For these reasons and others discussed further below, the FTC is deeply mistaken in suggesting that the damages for infringement should be set at the efficient price that would be struck at an earlier time in a voluntary contract that was not in fact entered into. On the contrary, the appropriate price for a privately negotiated contract is, from the perspective of overall social welfare, not the appropriate price for a damages award after litigation, because the price in a litigation setting should include the litigation and other costs imposed on the patentee by the failure of the infringer to either get a license or design around.

\section{The Effectiveness of Damages Approaches that Encourage Private Ordering}

More generally, the purposes of any damage rule for commercial contracts are not solely to provide the injured party with the same payment that it would have received if there had been no breach. That measure is inadequate even in the simple situation when the buyer covers in the market for a standardized good after the seller's breach. In those cases, the contract/market differential does not represent the appropriate damage level, because it ignores the costs needed to acquire the cover. ${ }^{59}$ The "what you would have been paid" measure is all the more inadequate in markets for non-fungible technologies, where infringement imposes a complex web of costs and destroyed value. For this reason, one of the functions of the correct damage rule is to reduce the frequency of infringements in the first place, so as to minimize the administrative costs of the system. An analog

\footnotetext{
${ }^{59}$ See for the appropriate rules, U.C.C. § 2-712 (2003) ("Cover"; Buyer's Procurement of Substitute Goods):

(1) After a breach within the preceding section the buyer may "cover" by making in good faith and without unreasonable delay any reasonable purchase of or contract to purchase goods in substitution for those due from the seller.

(2) The buyer may recover from the seller as damages the difference between the cost of cover and the contract price together with any incidental or consequential damages as hereinafter defined (Section 2-715), but less expenses saved in consequence of the seller's breach.

The economic "cost of cover" may also include loss of value because identical cover is not available, as where the buyer of a long-term contract is forced to find its cover in a short-term market. See, e.g., Missouri Furnace Co. v. Cochran, 8 F. 463 (W.D. Pa. 1881)
} 
to willful patent infringement is the conscious decision of one landowner to cut the timber that he knows is owned by his neighbor. In these cases the standard measure of damage is not the value of the timber to the owner less the cost he saves because the trespasser has cut the timber. Rather it is the full value of the timber, without any offset to the defendant for the value of the labor added. The reason for this conscious overestimation in damages is to make it clear to willful converters that they are always worse off from their actions than they would have been if they had entered into voluntary transactions with the property owner. ${ }^{60}$ The damage rule thus guides would-be converters into voluntary transactions so as to reduce the number of occasions where damages have to be calculated in the first place. The treble damages rule for willful patent infringement follows the same logic, and helps achieve the underlying policy goal of strongly motivating voluntary contracting in preference to unilateral expropriation.

Thus, the traditional perspective of the law of patent damages - that damages awards should ensure that patentees are no worse off in cases of infringement than they would have been had voluntary licensing occurred ex ante ${ }^{61}$ - has it right. Timely private contracting can create value, by ensuring that the patentee is made no worse off by the implementer's expropriation through infringement. Sensibly, the law puts the risk of value destruction from infringement on the infringer, which implies that infringement is likely to leave the infringer worse off than he would have been by taking a license. The FTC is, of course, correct as a matter of law that damages against non-willful infringers are "not meant to be punitive." ${ }^{\circ 2}$ But damage rules in patent law that allocate these infringement costs on the doorstep of the infringer do not cause "punishment." Rather, they provide a rational allocation of risk that encourages those interested in using patented technologies to identify and contract with patentees before they put the patented technology to significant use. The correct government mission is more about guiding behaviors over time, in the dynamic sense, than it is about apportioning value between claimants at any given time. If potential patent infringers don't have incentives to do their homework and either get licenses to patented technologies or design around them, they will rationally elect to engage in uncoordinated infringement, destroying value in multiple corners of the IP marketplace. The bottom line is that the social goal of the patent system and its attendant damage rules is not to punish (let alone reward) infringers, but to guide them not to infringe.

\section{E. Costs Imposed on Everyone in the IP Market by the FTC Approach}

Although the FTC Report pays lip service to the necessity of deterring infringement, ${ }^{63}$ an optimal damage rule should deter more infringements than those that are knowing and willful. The costs reviewed above all result from all unlicensed infringements, regardless of the defendant's mental state. Thus, it is critical to motivate manufacturers to seek out potentially relevant patents of which they are initially unaware, and to obtain licenses early in the process. Awarding treble damages and fees only to willful infringers cannot accomplish this important goal. Indeed, the willfulness rule can create the perverse incentive of inducing a studied ignorance of patents in the field. ${ }^{64}$

The FTC Report also argues that higher post-trial "reasonable royalty" damages based on the "valid and infringed" assumption offers a sufficient deterrent to infringement. ${ }^{65}$ But that deterrent effect is overstated. For example, even when there is certainty that users infringe a valid patent, each such infringer enjoys a non-trivial

\footnotetext{
${ }^{60}$ See Oliver Wendell Holmes, JR., The COMMON LaW 97 (1881).

${ }^{61}$ As the Federal Circuit put it:

A patentee is entitled to no less than a reasonable royalty on an infringer's sales for which the patentee has not established entitlement to lost profits. The royalty may be based upon ... the supposed result of hypothetical negotiations between the plaintiff and defendant. The hypothetical negotiation requires the court to envision the terms of a licensing agreement reached as the result of a supposed meeting between the patentee and the infringer at the time infringement began.

Rite-Hite Corp. v. Kelley Co., Inc., 56 F.3d 1538, 1554 (Fed. Cir. 1995).

${ }^{62}$ FTC REPORT at 20.

${ }^{63} \mathrm{Id}$. at 174

${ }^{64}$ See, e.g., Mark A. Lemley \& Ragesh K. Tangri, Ending Patent Law's Willfulness Game, 18 BerKelEy TECH. L.J. 1085, $1100-01$ (2003) (explaining that the willfulness doctrine "creates a strong incentive not to read patents'); Alan Devlin, The Misunderstood Function of Disclosure in Patent Law, 23 HARV. J.L. \& TECH. 401, 404 (2010) ("[T]he ever-looming danger of treble damages resulting from a finding of willful infringement creates perverse incentives to remain ignorant of patented technology.'); Note, The Disclosure Function of the Patent System (or Lack Thereof), 118 HARV. L. REV. 2007, 2020 (2005) (referring to a "perverse incentive for potential infringers not to become too aware"); Robert Greene Sterne, et al., The 2005 U.S. Patent Landscape for Electronic Companies, 823 PLI/Pat 293, 353-54 (March 2005) (reporting that "many companies implemented policies to discourage or forbid patent searching by inventors and patent attorneys").

${ }^{65} \mathrm{Id}$.
} 
chance that it will escape detection or benefit from an erroneous adjudication of non-infringement or invalidity. Unless the damages award is increased - beyond what a "valid and infringed" assumption would yield - to account for this effect, the incentive to infringe rather than take a license would remain.

One key feature of any remedial regime is to encourage private ordering that generates adequate incentives for future inventors and their contracting counter-parties to make and commercialize future technologies. Private licensing under the current legal regime has an empirically strong record of motivating investment in both upstream innovation and downstream implementation, in both standardized and nonstandardized industries. As we discuss below, the FTC Proposal would predictably depress returns on investment in R\&D substantially.

The FTC's zeal to protect infringers is misguided: law and policy should be concerned with using voluntary licenses to get the proper trade-offs between innovators and implementers. Investments in development of new technology come on the front end and are ongoing. Patentees and their contract partners face serious risks, toiling over long periods of time, striking many dry wells, before they enjoy any market rewards. In contrast, infringers generally enjoy numerous advantages over patentees, if only because they know something of the value of a patent that they choose to infringe. ${ }^{66}$ In addition, successfully developed products and distribution channels are by their nature difficult to keep secret and can serve as working models for competitors to follow, thereby saving them the cost of weeding out worse alternatives. In addition, published patents must teach others how to practice the invention or the patent will be invalid. Again, second movers enjoy a lower cost of capital as investors become educated about the technology's specific risks and potential for profit. ${ }^{67}$ Similarly, education of consumers and stimulation of consumer demand will benefit all competitors equally. Indeed, the arrival of a competitor into the market will force the original patentee (or early licensees) to incur added costs of brand advertising, on top of the costs of more general product advertising already incurred. For all of these reasons, careful attention must be paid to allowing those who invest on the front end in the process of inventing and commercializing new technologies to recoup the return they expect the market may generate for the successes they generate. Instead, the FTC's Proposal not only advantages infringers over innovators, but also advantages infringers over early voluntary licensees.

\section{F. Artificial Constraints Imposed on the Market by the FTC Approach}

The FTC's few anecdotes about apparent "outlier" cases of excessive royalties or damage awards are not sufficient to suggest that present incentives are misaligned and certainly provide no justification for regulatory "caps" on either royalties or damages. As with any natural phenomena, the value of innovations will be distributed over a broad range, some low (often zero or negative) and some high — even very high. Similarly, any well-functioning adjudication system will sometimes award damages on the high side of some hypothetical "economic perfection," and sometimes on the low side. Of course, it is the ex ante prospect of high returns that bring inventors in at the front end. To attempt to tamp down the high-end returns after they are realized, without equally increasing the returns on the low end of the distribution, will simply drive down the ex ante anticipated return on investment, thereby discouraging investments in the next innovation cycle. That would deprive everyone in the IP and product marketplace - including both manufacturers and consumers - of the next innovation.

Similarly, the FTC's proposal to value IP as of a time prior to standardization for purposes of damages awards is neither neutral nor rational. Precedent since at least Georgia-Pacific has long used a "reasonable royalty" measure of patent damages that is based on an estimate of the royalty that the parties would have agreed to in a negotiation conducted at the time of first infringement. ${ }^{68}$ In the case of standards-essential patents, the

\footnotetext{
${ }^{66}$ See, e.g., Joseph Farrell \& Garth Saloner, Standardization, Compatibility and Innovation, 16 RAND. J. ECON. 70 (1985) (formally describing second-mover advantages); Joseph Farrell \& Garth Saloner, The Economics of Horses, Penguins and Lemmings, in PRODUCT StANDARDiZATION AND COMPETitive STRATEGY 1 (H. Landis Gabel ed., 1987) (providing illustrative examples of second-mover advantages).

${ }^{67}$ See U.S. Congress, Office of Technology Assessment, Pub. No. OTA-BP-ITC-165, InNovation and Commercialization of EMERGING TECHNOLOGY 3, 20-96 (1995).

${ }^{68}$ As the Federal Circuit has stated on several occasions: "The hypothetical negotiation requires the court to envision the terms of a licensing agreement reached as the result of a supposed meeting between the patentee and the infringer at the time infringement began." Minks v. Polaris Indus., 546 F.3d 1364, 1372 (Fed.Cir. 2008) (quoting Hanson v. Alpine Valley Ski Area, Inc., 718 F.2d 1075, 1078 (Fed.Cir. 1983)). See also, Wordtech Sys., Inc. v. Integrated Networks Sol'ns, Inc., 609 F.3d 1308, 1319 (Fed.Cir. 2010) ("The hypothetical negotiation 'attempts to ascertain the royalty upon which the parties would have agreed had they successfully negotiated an agreement just (footnote continued)
} 
FTC strongly urges the radical change of pushing that "hypothetical negotiation" back to a time before the standard was adopted, on the ground that the articulation of the standard marks the time at which the infringer becomes "locked in" to use of the technology. ${ }^{69}$

The selection of this particular time makes one of two mistakes. Either it ignores the fact that the risk of hold-up is bi-directional, or it is intentionally calculated to empower the infringer to retroactively "hold up" the patent owner so as to drive damages awards (and hence negotiated license fees) as low as possible. If the implementer is "locked in" and vulnerable to hold-up once it has made "sunk costs" investments in a particular technology, so too is an innovator "locked in" to its technology after it has made the R\&D investments necessary to develop that technology. Any licensing negotiation conducted at this particular time may leave the innovator no alternative but to accept a price below what it would have agreed to in a negotiation held before it had incurred those R\&D costs. Thus, the FTC Proposal rather explicitly invites courts to generate opportunities for hold-up of innovators by infringing manufacturers.

It is also important to appreciate that pegging the damage award to any specific time, regardless of when the expropriating infringement occurs, almost inevitably mis-values the injury by giving - at far below market value - potential infringers an option to engage in opportunistic behavior, to the disadvantage of innovators. By presuming the government should select one fixed measure of a patent's value, the FTC Proposal would seriously impede the ability for markets to shift as they must over time to recognize the ever-changing value of assets. A host of market, technological, and other environmental factors operate over time to increase and decrease the value of particular patented technologies. These include changes in the demand for particular technologies over time as a result of economic growth, changes in consumer preferences, changes in production methods, the development of new products, and changes in transaction methods. They also include the introduction of competing technologies (decreasing value) or the development of complementary technologies (increasing value) as well as decisions by SSOs and government regulations. Each of these factors is relevant to determining the actual value provided by particular technologies.

The FTC's "incremental value" standard raises similar problems. It overlooks the reality that the incremental value provided by a technology must inevitably change over time with the movement in other costs of production, market preferences, complementary technologies, and available alternatives. To tie infringement damages to incremental value pegged at a fixed time in the past (before standardization, in the case of standardized technology) is to invite opportunistic behavior by manufacturers, who will face attractive incentives to move into the market and commence infringing should it become evident that the patent provides greater value to them than they had estimated at the pre-standardization (and low information) stage.

The FTC's proposal to "lock down" the potential damage recovery to the value of the patents at an early date in the value-creation process also distorts efficient market behavior. That rule would enable manufacturers to shift a great deal of risk onto the innovator and those "early adopter" manufacturers who do take licenses (and who instead should perhaps be rewarded for early risk taking). The infringer should not get any collateral benefit because it chose not to negotiate and commit to a license at the pre-standardization ex ante moment selected by the FTC. At that early time, the technical and market success of the technology was not yet known; the scale and riskiness of investment necessary by manufacturers to commercialize it was speculative; the intensity of competition from other manufacturers and other standards was unknown; capital, if needed, would be expensive risk capital. In this context, the innovator might indeed accept a relatively low rate to induce the manufacturer to take a license and assist in shouldering these risks. But this the late-coming infringer did not do. Instead, the infringer has kept its options open, moving into the market only after numerous risks and costs have been reduced or eliminated by others. The viability of manufacturing the implementing devices has been established; consumer demand has been created and proved; the size and price structure of the market is known; the nature of the competition is observable; the cost of capital of the infringer thus falls below the level it was for those who created the market.

FTC's proposed "time of standardization" hypothetical negotiation for patents subject to a RAND commitment is also a rigged construction that would play out badly over time for everyone in the IP marketplace. It combines disparate elements of traditional damage formulas in a way that is biased against the patentee. The FTC selects this time because the manufacturer has yet to incur any standard-specific sunk costs

before infringement began,' and 'necessarily involves an element of approximation and uncertainty."') (quoting Lucent Techs. v. Gateway, Inc., 580 F.3d 1301, 1324-25 (Fed.Cir. 2009)).

${ }^{69}$ FTC REPORT at 193. 
(while the innovator has sunk all of its $\mathrm{R} \& \mathrm{D}$ costs) affording the manufacturer optimal bargaining power over the patentee. But if we travel back to a pre-standardization moment, then no RAND obligation yet existed, and the patentee negotiating at that time retained its full power to exclude anyone who was not prepared to agree to an arrangement that provided adequate compensation for the patentee's investments (potentially with a view towards exploiting its inventions in a proprietary manner or contributing them to a different and competing standard). Yet the FTC is emphatic that the power to exclude and the value of that power must be ignored from its reconstituted hypothetical negotiation that fails to correspond to actual rights and incentives that real parties face at any point in time. The simple reality is that before a standard is set, it just is not clear whether a patent might become more or less valuable. Some upward pressure on value may be created later to the extent that the patent is important to a standard that is important to the market. In addition, some downward pressure may be caused by a later RAND commitment or some other factor, such as repeat play. The FTC seems to want to give manufacturers all of the benefits of both of these dynamic effects by in effect giving the manufacturer the free option of picking different focal points for elements of the damages calculations. The patentee is forced to surrender all of the benefit of the upward pressure while the manufacturer is allowed to get all of the benefit of the downward pressure.

In short, there is no economic basis to equate a manufacturer that is willing to commit to license terms before the adoption and launch of a standard, with one that instead expropriates patent rights at a later time through infringement. The two bear different risks and the late infringer should not pay the same low royalty as a party that sat down at the bargaining table and may actually have contributed to the value of the patent through its early activities. There is no economically meaningful sense in which any royalty set higher than that which a "willing licensee would have paid" at the pre-standardization moment somehow "overcompensates patentees by awarding more than the economic value of the patent." damages, which measures the value of the good (the license) at the time it is expropriated by unilateral action of the infringer (the time that infringement begins) correctly takes into account the informational and risk advantages enjoyed by the infringer.

\section{G. The Ineffectiveness of Incremental Value in Calculating Damages}

The FTC proposes that courts should treat so-called "incremental value" as a "cap" on whatever measure of damages that other methods of valuation might produce. In fact, it is neither possible nor desirable for courts to do so.

First, it is a serious mistake to suppose that there is any such unique number that counts as the incremental value of a patent. Generally, different buyers will derive different benefits from implementing any particular technology. These differences will depend on the buyer's complementary assets, other technologies, final products, organizational structure, technological knowledge, and many other factors. Also, because different buyers have different benefits from any particular technologies, the next best alternative for each may differ whenever multiple alternatives are available in the marketplace. Different buyers may rank alternatives very differently, some preferring technology $A$, some technology $B$, and others technology $C$, either alone or in conjunction with other processes, including some covered under trade secrets. As a consequence of these factors, buyers are likely to derive very different incremental benefits for any particular technology. Would those market participants with the highest, lowest or average benefits provide the principled basis for the "incremental value pricing" regulation?

The bottom line is that because buyers differ, there is no uniform "incremental value price" around which to organize the FTC's proposed ratemaking venture. Because the concept of "incremental value" fails to describe some measurable attribute that meaningfully relates to the diverse and dynamic marketplace of the real world, it should not be given any prescriptive weight.

Nor can it possibly be a right answer to seek "the incremental value for this particular infringer," as the Report's reference to "the maximum rate the infringer would pay" suggests. ${ }^{71}$ The FTC's approach would result in highly varied "prices" for the same patent to different manufacturers, thereby introducing two vices. The first is to violate the RAND policies without cause. The second is to potentially reward the inefficient infringer.

Second, although the whole concept of "incremental value" is a useful intellectual construct when describing purchaser conduct in simplified academic models, the complexity of the real world makes it

\footnotetext{
${ }^{70}$ FTC REPORT at 170.

${ }^{71} I d$. at 168 .
} 
essentially useless as a tool for prescribing pricing. A single patented invention will often have multiple identifiable "alternatives:" which is the "next best" may vary from purpose to purpose and user to user. Ultimately, the issue may turn fundamentally into disagreements of opinion rather than those of fact. What "incremental value" the patent provides across any one of those alternative pairs will be the subject of extensive speculation. These difficulties will compound when the same test is applied to each of the multiple standards incorporated into a complex device using a large number of patented technologies, each of which has numerous and debatable "alternatives." It is to avoid such piecemeal disputes that the relevant licenses in the real world are consistently negotiated on a portfolio basis. The complex institutional framework makes it apparent that no meaningful "incremental value" calculation can be done.

Third, as the discussion above suggests, Georgia-Pacific is wise to give the greatest weight to evidence of actual market pricing (through actual licenses) of the patents in dispute or, when need arises, of comparable patents. The FTC Report flies in the face of RAND commitments if it means to suggest that courts should use "incremental value" as a cap even over valuation established by reference to comparable licenses, once again signaling that infringers may obtain a price advantage over those who negotiate licenses. We do not need to elaborate on the perverse incentives and results that this signal would produce.

Fourth, while this paper focuses on patents incorporated into standards subject to RAND commitments, the FTC's recommendations are not so narrowly limited. We thus note briefly that the FTC's approach to patent damages entirely omits the value of the patent owner's right to exclude, which includes the right to grant an exclusive license or to limit the class of nonexclusive licensees. ${ }^{72}$ The FTC would give an infringer's right to expropriate priority over the patent owner's right to exclude.

The FTC's approach to measuring reasonable royalty is very specific: "The Commission recommends that courts award reasonable royalty damages consistent with the hypothetical negotiation analysis and willing licensor/willing licensee model." The FTC Report defines this model so narrowly that it forecloses the value of an exclusive licensee. Its key passage runs as follows:

Concerns about compensating unproven lost profits damages should not be allowed to inflate a reasonable royalty damage award beyond the maximum amount that a willing licensee would have paid. Arguments that the patentee would reject that maximum amount are based on an assumption that the patentee could have made more by not licensing, which means it sold a product. But if the patentee were better off selling or licensing the invention exclusively, it should be entitled to damages based on lost profits. When a patentee has failed or chosen not to prove its lost profits, allowing amorphous or unproven claims of harm to override the hypothetical negotiation's requirement of a willing licensee risks damage awards that are unconnected to the economic value of the invention. This result misaligns the patent system and competition policy by overcompensating patentees compared to a market absent infringement. ${ }^{73}$

Having thus ruled out royalties from exclusive licensing, the FTC report then recommends that all but one of the 15 traditional factors for determining reasonable royalties from the well known Georgia-Pacific case be eliminated from consideration by the courts. ${ }^{74}$ The only factor that remains is number 15: "The amount that a licensor (such as the patentee) and a licensee (such as the infringer) would have agreed upon (at the time the infringement began) if both had been reasonably and voluntarily trying to reach an agreement."

\footnotetext{
${ }^{72}$ The FTC approach also runs afoul of the classic make-or-buy decision that has been famously studied in depth over the past century of economic research into the boundary between the business firm and the market. That extensive literature has conclusively shown that the serious efficiency tradeoffs are so varied and complex that one solution most assuredly does not fit all cases. The FTC states that lost profits damages will never be appropriate when the patentee does not manufacture a product. FTC REPORT at 143. But why? The essence of efficient markets is specialization by function. There is nothing sinister or illegal about gathering together a suite of patents that is then licensed on an exclusive or nonexclusive basis to other parties that use them to manufacture. The nonexclusive license is of critical importance in this regard because it allows the same advanced technology to be licensed to firms in an entire industry. The lost profits measure of damage is therefore as appropriate for these licensing cases as it is for any manufacturing cases. There is no reason whatsoever for the law to favor those firms that integrate internally over those that integrate across the market. It therefore is mistaken to undermine the willingness to license by depriving the licensee of the remedies that make the system go. As between the licensor and licensees, contracts can handle the relevant issues.

${ }^{73}$ FTC REPORT at 172.

${ }^{74}$ Georgia-Pacific Corp. v. United States Plywood Corp., 318 F.Supp. 1116, 1120 (S.D.N.Y. 1970) (reviewing fifteen factors).
} 
The FTC report characterizes this hypothetical bargain between the infringer and the patentee-a willing buyer and a willing seller-as representing the competitive marketplace. But its calculations bear no relationship to how royalties are calculated in any known competitive market. A competitive market allocates goods to the highest value users. By that standard, a rational patentee wants to license the patented technology to those users offering the highest royalties. ${ }^{75}$ The forced bargain that the FTC envisions between the patentee and the infringer need not be the best bargain and need not be the bargain that would be observed in the market.

As a matter of general principle, economic theory has long recognized that any measure of value must include the opportunity costs borne by an asset holder. But the patentee's opportunity cost of being forced to be a "willing" licensor to any and all infringers strips it of opportunity to license someone else who values the technology more than the infringer. That higher value user may take advantage of economies of scale, transaction efficiencies, and market returns associated with exclusivity. Even with a RAND commitment, the patent owner retains the valuable right to exclude (not merely receive later compensation from) manufacturers who are unwilling to accept reasonable license terms. Indeed, the right to exclude influences how those terms should be calculated, because it is quite likely that prior licensees in at least some areas will pay less if larger numbers of parties are allowed to use the same technology. Those interactive effects are ignored in the FTC calculations.

\section{H. The Fundamental Unsoundness of Taking Into Account the Infringement-Specific Investments of the Infringer}

After arguing that "transaction [that is, infringement] specific investments" by the infringer create an opportunity for "hold-up," the FTC implicitly proposes that to avoid this alleged "hold-up," the infringer's investment costs should be deducted from any patent infringement damage award:

Recommendation. To prevent damage awards based on switching costs, courts should set the hypothetical negotiation at an early stage of product development, when the infringer is making design decisions and before it has sunk costs into using the patented technology. ${ }^{76}$

Accordingly, the FTC's hypothetical negotiation framework calculates the value to the infringer before sinking costs of using the patented technology, which effectively means that the infringer's value is net of the costs of using the patented technology. The FTC's hypothetical negotiation essentially deducts the infringer's investment costs from any patent infringement damage award. This has the perverse effect of reducing the value of any patent infringement damage award by at least an amount equal to the infringer's investment costs. This proposal would injure innovators and create seriously perverse incentives for manufacturers.

First, if manufacturers invest with varying efficiency in specific technologies, then subtracting "infringement specific investments" from infringement damage awards will generate differential pricing for different manufacturers for the same (expropriated) license rights. But it cannot be that either the "fair market value" of a license (or a "reasonable" fee in the case of a RAND commitment) varies on a case-by-case basis with the particular efficiencies of the individual manufacturer.

Second, this differential pricing will strip licensed manufacturers of their hard-earned advantage by favoring infringers.

Third, the FTC proposal eliminates the legitimate competitive advantage of more efficient manufacturers through a subsidy for inefficient manufacturers. This new doctrine makes the innovator and its licensees into insurers for inefficient investment by infringers.

Fourth, the FTC proposal violates the basic patent law principle that the patent-owner should not be made worse off by the infringer's choice to infringe rather than take a license. If the value of a license is set with reference to the value of the contribution of a manufacturer of average efficiency, then an inefficient manufacturer would be unable to afford the license and thus stay out of the market. Most of the lost sales of that manufacturer will go to other, more efficient manufacturers who pay market rate royalties to the patent owner. It

\footnotetext{
${ }^{75}$ The FTC Report seems to recognize this possibility whose implications it ignores in examining damages options: One way a patentee can innovate is to develop and commercialize the invention itself. For a patentee producing a patented product, the primary importance of the patent is often the right it confers to exclude competitors from making and selling a competing product incorporating the patented technology. Often the most effective way to remedy infringement in this context is by awarding the patentee its profits on sales of the patented product that it lost due to the infringement. FTC REPORT at 150

${ }^{76}$ FTC REPORT at 22.
} 
makes no sense to allow inefficient manufacturers the option to pay below market "reasonable royalty" in ways that decidedly injure the patent holder and more efficient licensees.

Finally, this unsound proposal also asks courts to mix yet another extremely speculative and debatable term into the damages equation. Even if the infringer's investment in infringing were somehow to be viewed as transaction specific, it would be practically impossible in litigation to determine what expenses were exclusively specific to developing the infringing device and what expenses had other actual or potential value to the infringer. Put differently, the extent of the infringer's costs that are specific to any hold-up and cannot be recouped are only those costs of retooling their investment towards non-infringing uses.

\section{The Stark Inconsistency Between the FTC's Approach and the Key Role Historically Played by Predictable Rules for Patent Enforcement in the Successful Commercialization of Inventions as Well as Overall Competition and Social Welfare}

In yet another mistake, the FTC gives inadequate weight to key concepts in law and economics when setting its rules for patent remedies. Predictable enforcement of patents provides appropriate incentives to make inventions and bring them to market. Those incentives are not merely directed to inventors. They necessarily reach all of the many actual and potential contracting parties the patentee must do business with for the technology to be commercialized. While some categories of interactions do count as hold-up, they are limited in practice and largely peripheral to the use of patented technology by SSOs. In other contexts, there are a host of institutional arrangements that parties use to significantly mitigate the risk of hold-up. And in settings involving interactions among strangers, the law has similarly evolved a host of other mitigating institutions.

All too often, patent skeptics voice fears that strengthening patents will bring a flood of patent lawsuits, grinding to a halt the wheels of future commerce. At the same time, some patent defenders insist that weakened patents will be so worthless that nobody will bother to get them. Much has been written on both sides of these debates, which we will not enter into here. However, one predictable structural effect of weakened patent enforcement deserves mention. Specifically, the changes proposed by the FTC will lead to subtle but important shifts in the commercialization of new technologies and the overall structure of the competitive landscape. Many of these changes will be to the benefit of large firms which have the means of exploiting their own inventions and capturing value through product sales, but to the detriment of overall levels of market innovation including efforts by smaller firms and entrepreneurial startups that rely on patent protections and licensing revenues. In addition, the FTC proposals reduce voluntary contracting and increase patent litigation and potential private and regulatory antitrust enforcement actions challenging negotiated license terms. The burdens of these developments will fall particularly heavily on startups and market entrants, again favoring well-funded incumbents. All of this will discourage the small-scale entrepreneurship that has historically been a prime catalyst of our high-technology economy.

Recent history has given us at least two striking natural experiments about how this works. ${ }^{77}$ The first tells the story of the presence of patents as a key to increased competition and commercialization. The second tells the story of the absence of patents as a key to monopoly.

Before 1980, the U.S., Europe, and Japan all had held the view that patents in the area of basic biotechnology could not overcome a range of vaguely defined so-called "public policy" objections. As a result, patents on basic biologicals were not reliably available or enforced. Patents on pharmaceuticals were. Then, thanks to the 1980 Supreme Court Chakrabarty decision, ${ }^{78}$ basic biologicals suddenly got to enjoy meaningful patent protection for both products as well as testing methods and devices. That change was only in the U.S. market, and only after 1980. The immediate result was remarkable revival, but only in the U.S., of small- and medium-sized biotechnology companies and a drastic increase in the number of new drugs and new medical devices brought to market. All of this new activity resulted in high rates of invention that occurred simultaneously with the renewed success of large pharmaceutical firms, whose own business opportunities increased with the higher rates of development. ${ }^{79}$

\footnotetext{
${ }^{77}$ See generally, F. Scott Kieff, Coordination, Property \& Intellectual Property: An Unconventional Approach to Anticompetitive Effects \& Downstream Access, 56 EMORY L. J. 327, 420-21 (2006).

${ }^{78}$ Diamond v. Chakrabarty, 447 U.S. 303 (1980).

${ }^{79}$ See, e.g., Heather Hamme Ramirez, Defending the Privatization of Research Tools: An Examination of the "Tragedy of the Anticommons" in Biotechnology Research and Development, 53 Emory L.J. 359 (2004) ("Since 1992, the number of biotech patents granted has increased substantially, and the industry has more than tripled in size. New biotech drug and vaccine approvals rose from two in 1982 to thirty-five in 2002.").
} 
The software industry offers a parallel story in a setting where the absence of patents was linked with the rise of a monopoly. The U.S. courts had allowed themselves to accept the view that patents on computer software and methods of doing business were, like patents on living organisms, inconsistent with a range of vaguely defined so-called "public policy" notions that stemmed from 1972 Supreme Court decision in Benson ${ }^{80}$ up through the 1980's and into the 1990's. It was only after the 1994 appellate court Alappat decision ${ }^{81}$ that the single biggest Microsoft competitor-Google - was able to come to market in the U.S., relying on strong patents and trade secrets. ${ }^{82}$ In the words of Judge Jerome Frank: predictable enforcement of patents helps give the Davids the vital slingshots they need to take on the Goliaths. ${ }^{83}$

These episodes should lead the FTC to rethink its position and should discourage others at home and abroad from following it. The bedrock of a sound patent policy lies in the firm and practicable enforcement of property and contract rights around patents. That fundamental decision lies at the foundation of the stable business relationships that drive the whole commercialization process. Absent that enforcement, most work will be done within firms and not among them. The gains from trade and specialization will therefore necessarily be curtailed, as will the public dissemination of knowledge that comes from patent filings. This will increase the threat of monopoly power, and decrease economic growth, job formation, as well as decrease the availability of innovation to consumers.

\section{CONCLUSION - A SOUND CASE FOR REGULATORY RESTRAINT}

The dynamic effects of the FTC Proposal are particularly ironic. Infringing firms will be encouraged to engage in non-cooperative strategic behavior when it pays for parties to ignore patents and spurn licenses ex ante. These firms will prefer instead to run the modest risk of suits for infringement given the decreased remedies ex post. Further, any early adopter firms that do take ex ante licenses would likely be put at a competitive disadvantage against infringers because those early adopters made the significant early investments necessary to develop products and markets for the licensed technology.

The key criticism of the FTC report relates to the basic principles of social and economic interaction. The law dealing with tangible property seeks to facilitate voluntary agreements rather than unilateral appropriation of the property of others. These principles apply with equal force to all forms of intellectual property. In the effort to see what is distinctive in IP, the FTC has lost sight of how that body of law connects to larger systems of property and contract that defines the parameters in which any liberal society must operate. Our hope is that once the FTC sees those connections, it will decide to significantly reign in the recommendations in its recent Report.

SSOs are wise in having not voluntarily adopted the rules for patent licensing terms that the FTC would now impose on all of them by judicial fiat. That's because those rules would create powerful incentives for behavior that would so significantly decrease overall value in the IP marketplace that from a true ex ante position, not even potential licensees would rationally chose to vote for them.

The FTC has not identified sufficient evidence to raise serious doubt about the current efficiencies of the IP marketplace. The default assumption should be that that the consensus SSO IP licensing policies and practices are well-tuned to ensure balanced incentives to all necessary participants in the chain of innovation and commercialization, both to make necessary investments, and to participate in the standardization process. And indeed, the available empirical evidence suggests that these existing rules and practices work well. If sound empirical evidence of a problem requiring legal intervention did emerge, then responses should be far more carefully targeted than the approaches in the FTC Report. They also should be far more attentive, through careful dynamic analysis, to the risks of unintended consequences such as creating perverse incentives for infringement, against licensing, and against the investment essential for later rounds of innovation.

The FTC advances no evidence for the alleged problems of patents and SSOs and fails to address the considerable evidence that markets and SSOs function effectively. The interests of consumers are well

\footnotetext{
${ }^{80}$ Gottschalk v. Benson, 409 U.S. 62 (1972).

${ }^{81}$ In re Alappat, 33 F.3d 1526 (Fed. Cir. 1994).

${ }^{82}$ According to its own patent information database (available at http://google.com/patents), Google is the assignee of 552 patents. U.S. Patent 6,285,999, the patent on PageRank, the foundational algorithm for Google's search technology, is owned by Stanford University and exclusively licensed to Google. Starting Up: How Google Got Its Groove, STANFORD MAGAZINE (Nov.-Dec. 2004), available at http://www.stanfordalumni.org/news/magazine/2004/novdec/features/startingup.html (last visited Aug. 1, 2011). Google also recently acquired over 1000 patents from IBM. Google Acquires Over 1,000 IBM Patents, CNET (July 29, 2011), http://news.cnet.com/830113506 3-20085418-17/ (last visited Aug. 1, 2011).

${ }^{83}$ Picard v. United Aircraft Corp., 128 F.2d 632, 643 (2d Cir. 1942) (Frank, C.J., concurring).
} 
represented by SSOs and competition among technology implementers who at the end of the day must make goods and services that people wish to purchase. Government interference with SSOs and innovation will only harm the interests of consumers, creating yet another example of government hold-up. ${ }^{84}$

For all of these reasons, a posture of regulatory restraint is appropriate; embracing caution against the proposal or adoption the types of changes to the current remedies for patent infringement that are in the FTC Proposal. The high costs of shifting a massive slice of the economy into a regime of judicial price regulation are not worth incurring just to address potential problems that are at most peripheral to the overall success of SSOs in particular and the IP marketplace in general.

\footnotetext{
${ }^{84}$ For other examples of government hold-up long studied in the economic literature, see supra note 20.
} 
Appendix A - Excerpts from Qualcomm License Agreements

While individual license agreements are regularly covered by confidentiality agreements that prevent their disclosure, Qualcomm licensing executives have informed us that the provisions quoted in the below table are excerpted from actual license agreements entered into with various licensees, by which Qualcomm granted rights extending to potential standards that had not yet been adopted at the time the license was negotiated and in some cases would not be adopted for some years.

Table 1. Excerpts from Qualcomm License Agreements

Excerpt from License Agreement

"Common Air Interface Specification" means the technical description of the DSCDMA air interface between cellular cell site or base station transceivers and Subscriber Units (also referred to as the "Air Interface Specification" or the "Specification").

"Common Air Interface" or "CAI" means the technical description of QUALCOMM's CDMA digital air interface specification for communication between Cellular cell site or other Cellular base station transceivers and Subscriber Units, including without limitation, the Mobile Station-Base Station Compatibility Specifications and the Mobile Station performance requirement specifications being developed by QUALCOMM.

"Common Air Interface" or "CAI" means the Telecommunications Industry Association (TIA) IS-95 digital cellular standard and any other CDMA Wireless standard that may be adopted by the TIA or other standards bodies in the Territory, and any de facto CDMA Wireless standard.

"Common Air Interface" or "CAI" means the technical description of QUALCOMM's CDMA digital air interface specification for communication between cell site or other Base Station transceivers and Subscriber Units as may become adopted as a standard by the Telecommunications Industry Association (TIA) and other international standards bodies.

"CDMA Wireless Industry Standard" means standards for public code division multiple access communications including but not limited to IS-95A, IS-96A, IS127, ANSI J-STD-008, the proposed ETSI UMTS standard, their subsequent releases, revisions and derivations, and any local and regional standards based substantially thereon, any wireless local loop or wireless PBX (private branch exchange) systems based substantially thereon, and the Globalstar Satellite System. For the purposes of this Agreement, including but not limited to determining whether a patent is a CDMA Technically Necessary Patent, CDMA Wireless Industry Standard includes all of the above-described standards and systems but does not include the GSM standard or any other standard which utilizes a TDMA over-the-air interface.
Licensee and Year

American Handset

Manufacturer, 1990

European Handset

Manufacturer, 1992

Japanese Handset

Manufacturer, 1993

Korean Handset

Manufacturer, 1993

European Handset Manufacturer, 1998 
"CDMA Applications" means all communications applications (regardless of the transmission medium) which operate using code division multiple access ("CDMA") technology, whether or not based on IS-95 Related Systems, cdma2000 or WCDMA, and irrespective of frequency band.
European Handset Manufacturer, 1999 